\title{
Systematic Review of Bird Response to Privately-Owned, Managed Pine Stands in the Southeastern U.S.
}

\author{
Kristine O. Evans ${ }^{1, *}$, Angela Larsen-Gray ${ }^{2}$, Darren Miller ${ }^{3}$ and Craig Loehle 4 \\ 1 Department of Wildlife, Fisheries and Aquaculture, Mississippi State University, P.O. Box 9690, \\ Mississippi State, MS 39762, USA \\ 2 National Council for Air and Stream Improvement, 1513 Walnut Street, Suite 200, Cary, NC 27511, USA; \\ alarsen-gray@ncasi.org \\ 3 National Council for Air and Stream Improvement, P.O. Box 9680, Mississippi State, MS 39762, USA; \\ dmiller@ncasi.org \\ 4 National Council for Air and Stream Improvement, 1258 Windemere Ave., Naperville, IL 60564, USA; \\ cloehle@ncasi.org \\ * Correspondence: kristine.evans@msstate.edu; Tel.: +1-662-325-3167
}

Citation: Evans, K.O.; Larsen-Gray, A.; Miller, D.; Loehle, C. Systematic Review of Bird Response to Privately-Owned, Managed Pine Stands in the Southeastern U.S. Forests 2021, 12, 442. https:// doi.org/10.3390/f12040442

Academic Editor: Jay R. Malcolm

Received: 3 March 2021

Accepted: 31 March 2021

Published: 6 April 2021

Publisher's Note: MDPI stays neutral with regard to jurisdictional claims in published maps and institutional affiliations.

Copyright: (c) 2021 by the authors. Licensee MDPI, Basel, Switzerland. This article is an open access article distributed under the terms and conditions of the Creative Commons Attribution (CC BY) license (https:// creativecommons.org/licenses/by/ $4.0 /)$.

\begin{abstract}
The southeastern U.S. is widely known as a bastion of privately-owned, managed pine (Pinus spp.) forests, comprised primarily of native pine species. The region supports high levels of biodiversity, but also a multi-billion-dollar forest products economy critical to socioeconomic stability of rural areas. We conducted a systematic review of studies focused exclusively on avifaunal associations within privately-owned, managed pine landscapes in the southeastern U.S. We used the Preferred Reporting Items for Systematic Reviews and Meta-Analysis framework to examine all available studies that evaluated aspects of avian diversity, abundance, and community composition across a suite of forest types, stand ages, and forest management practices within southeastern managed pine systems in the last 70 years. We screened 160 records through primary database searches, and 1696 secondary records from supplemental searches and other sources, and identified 103 relevant articles for inclusion. As expected, although there is no single forest management practice that best provides for avian communities, we found practices that: (1) involve prudent site preparation; (2) promote forest thinning and intermediate management practices; (3) provide nonpine vegetative cover; (4) supply fine- and meso-filter resources such as retained snags and coarse woody debris; and (5) promote heterogeneity in cover types, largely enhanced value of southeastern managed pine systems to avian communities. Overall, it appears that avian communities can be best maintained by providing a diverse mosaic of forest conditions in managed pine landscapes. Key research gaps include improving understanding avian population demographics, such as survival, reproduction, and dispersal.
\end{abstract}

Keywords: plantation forestry; birds; avian community; managed pine; Pinus spp.; southeastern U.S.; stand establishment; thinning; forest management; silviculture

\section{Introduction}

The year 2020 marked an important moment for the global conservation community as comprehensive, decadal assessments of global biodiversity targets were used to evaluate the state of the world's ecosystems [1,2]. Forests were of particular interest as they harbor much of the world's terrestrial biodiversity and continue to experience substantial losses worldwide [2]. Specifically, planted forests now comprise $7 \%$ of global forest cover and, since 1990, have more than doubled in area to 294 million hectares worldwide [2]. Globally, $45 \%$ of planted forests are now considered "intensively managed plantations" aimed to maximize timber volume [2]. These forests are typically planted to even-aged, regularly spaced, native or exotic mono- or polycultures [2]. Despite a relatively small global footprint, planted forests provide up to $66 \%$ of global roundwood production [3]. 
There is debate regarding the biodiversity implications of planted forests, with particular concern about biodiversity losses when natural forest communities are replaced with stands planted to one or more tree species [4,5]. Global evaluations have documented both negative and positive outcomes from planted forests with respect to biodiversity and other environmental conditions $[4,6,7]$. In some cases, biodiversity can benefit from ecosystem services that planted forests provide on sites considered degraded [4]. Moreover, planted forests may relieve pressures to convert natural forest to meet fiber demands, allowing natural forests to be set aside or managed for other objectives [4]. However, the effects of planted forests on biodiversity, both positive and negative, depend on many factors, including stand type, size, age, structure, past land use, and duration landscapes have been in a plantation system $[4,6]$.

As much as $96 \%$ of planted forests in North America are planted with native tree species (compared to only 3\% in South America) [2]. The southeastern U.S. is a widely known bastion of privately-owned, managed pine forests, comprised primarily of native loblolly (Pinus taeda L.), slash (P. elliottii, Engelm), shortleaf (P. echinata, Mill.), and longleaf (P. palustris, Mill.) pine plantations [5]. The region contains the second largest area of private planted forest worldwide (as of 2006) and supports a multi-billion-dollar forest products economy critical to the socioeconomic stability of rural areas [5]. Pines in the Southeast were often a locally dominant forest type pre-European settlement, due to the predominately sandy soils and frequent burning by Native Americans [8-10]. Following many years of farming post-European settlement, much agricultural land was abandoned and subsequently planted or succeeded to pine. Thus, it is reasonable to suspect that stands planted or naturally regenerated with native pine provide key food and cover resources for regionally and locally adapted flora and fauna [4].

The southeastern U.S. is also one of the most biodiverse regions of North America, and rural areas are under substantial threat of land conversion due to a rapidly expanding urban footprint [11,12]. Given projected pressures from urban expansion and concerns for ecosystem sustainability under a changing climate, economically valuable managed pine systems are a potential future stronghold for biodiversity in rural southern landscapes [13]. Large-scale landscape initiatives like Keeping Forests (keepingforests.org (accessed on 4 October 2020)) and the Southeast Conservation Adaptation Strategy (secassoutheast.org (accessed on 4 October 2020)) have recognized the increasing importance of managed forest systems to sustainability in the region. However, despite the tremendous biodiversity in southeastern forest ecosystems and advances in forest management towards more sustainable silvicultural practices, there remain questions about the compatibility of managed pine systems and biodiversity objectives. Since 1995, many companies have enrolled in forest certification programs, such as the Sustainable Forestry Initiative (SFI; forests.org (accessed on 4 October 2020)) or the Forest Stewardship Council's Forest Certification Standard (FSC; fsc.org (accessed on 4 October 2020)) (see acronym list in Table 1). Certification programs are considered an effective means to conserve biodiversity through standards that guide stand- and landscape-level management [14-16]. SFI and FSC standards were recently found to be "stringent" with respect to biodiversity objectives [17]. However, effectively measuring biodiversity outcomes from forest sustainability programs remains a substantial challenge [5].

Birds are useful as indicators of ecosystem integrity and biodiversity [18]. Early successional, shrubland, and mature forest bird communities may maintain populations on privately-owned, managed pine landscapes in the southeastern U.S. [19,20]. Thus, birds may be particularly relevant to assessing progress toward meeting biodiversity objectives of lands managed under forest certification programs. A recent global meta-analysis suggested that planted forests support an "impoverished subset of native avifauna" [7]. However, the meta-analysis by Castano-Villa et al. (2019) primarily examined regions dominated by exotic tree plantations and recognized that many different aspects of planted forests (e.g., forest type, stand age and/or rotation length, stand size, management strategy, connectivity), operating at local and landscape scales, affect avian community use of these 
forests. Plantations of native tree species generally have reduced negative effects on native bird communities, as compared to plantations of exotic species, because of retention of many natural ecological relationships favoring native biodiversity [7]. Given the increasing importance of privately-owned, managed pine forests to conservation and sustainability of rural landscapes in the southeastern U.S., it is important to understand how native forest plantations affect avian communities across the region and identify key knowledge and application gaps that need to be addressed with future research. Therefore, we conducted a systematic review of studies focused exclusively on avifaunal associations within managed pine landscapes in the southeastern U.S. We examined all available studies that evaluated aspects of avian diversity, abundance, and community composition across a suite of forest types, stand ages, and forest management practices within southeastern managed pine landscapes over the last 70 years. We provide a comprehensive synthesis of avian community response to various aspects of southern pine management on privately-owned, managed forests and identify important areas for future research to enhance understanding of avian communities managed pine systems.

Table 1. List of acronyms and their associated descriptions relative to factors of southeastern U.S. pine management and listed in order of appearance in the text.

\begin{tabular}{cc}
\hline Acronym & Description \\
\hline SFI & Sustainable Forestry Initiative \\
FSC & Forest Stewardship Council \\
PRISMA & Preferred Reporting Items for Systematic Reviews and \\
SEAFWA & Meta-Analysis framework \\
CWD & Southeastern Association of Fish and Wildlife Agencies \\
SMZ & Coarse-woody debris \\
Streamside management zone
\end{tabular}

\section{Materials and Methods}

We conducted a systematic literature review using the Preferred Reporting Items for Systematic Reviews and Meta-Analysis (PRISMA) framework [21] to evaluate published literature related to avian communities in southeastern managed pine systems. The PRISMA framework includes initial identification through database searching, exclusion of duplicates, title-abstract screening, and full-text article screening for eligibility. We excluded the final meta-analysis component of the PRISMA framework, as our intention was not to evaluate effect sizes in a comparative context but to assess overall contributions of managed pine to avian communities in the region. We used Web of Science and SCOPUS as primary search engines, and supplemented primary literature searches with articles found in Elsevier Science Direct and via full-text searches in Google Scholar, collaboratorprovided bibliographies, and secondary citations found within papers identified in review results. We implemented a series of terms and Boolean operators employing consistency with search terms within the limits of database engine capacity (Table S1). Web of Science allowed for combinations of sets of operators, and we selected search by title (TI), abstract $(\mathrm{AB})$, and author key words (AK). We restricted our geographic area to all or parts of 13 southeastern U.S. states that comprise the bulk of managed pine coverage and exhibit similarities in management practices (Figure 1; Table S1). We also included a geographic search term for "Southeast" to identify regional publications or those that incorporated multiple southern states. We screened out publications from Texas, Oklahoma, Kentucky, Tennessee, and Virginia that were outside of the general range of managed loblolly, shortleaf, or slash pine. 


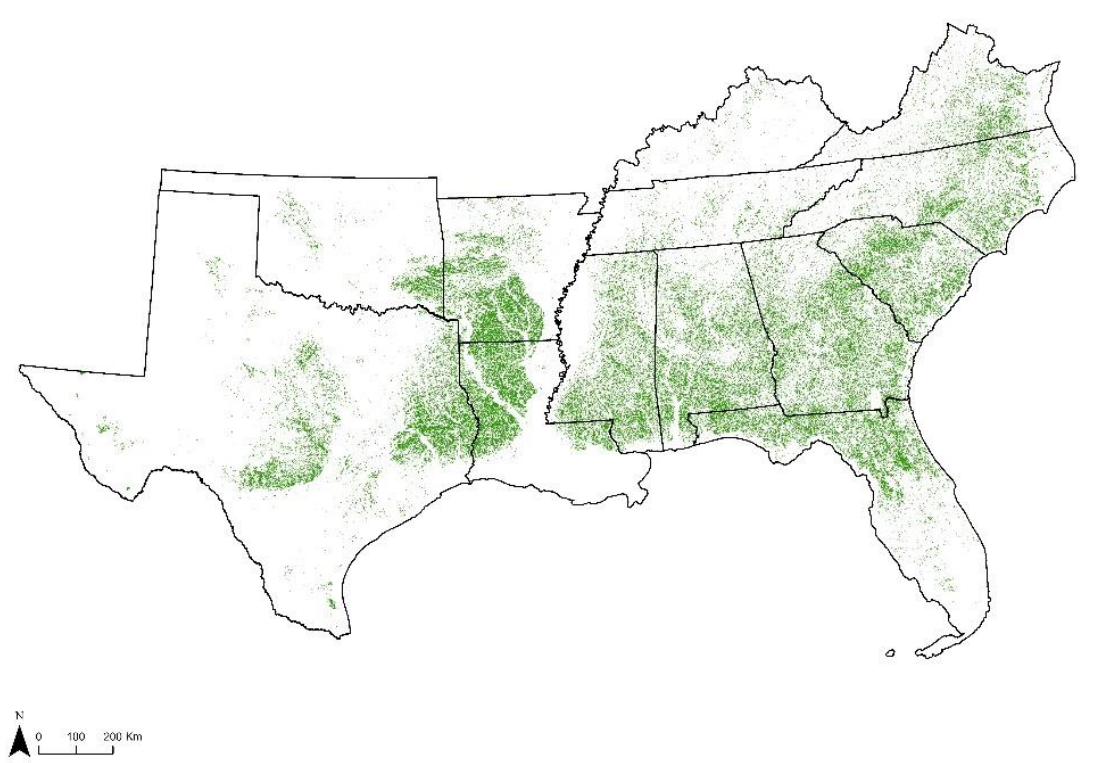

Figure 1. States (USA) within the area of study (including Alabama, Arkansas, Florida, Georgia, Louisiana, Mississippi, North Carolina, South Carolina, Virginia, and portions of Kentucky, Oklahoma, Tennessee, and Texas with managed pine) overlaid with total evergreen land cover (public and private) on [22]) as an approximation of the extent of pine-dominant systems in the southeastern U.S.

In general, search terms included the words "pine", "plantation", "bird", "avian" or "avifauna", "Southeast", "diversity" or "richness" or "community", "intensive forestry" or "forest management", "loblolly" or "shortleaf" or "slash" pine, the aforementioned geographic areas, and several other forest management terms (Table S1). We excluded the term "longleaf" due to differences in establishment and intermediate management practices used in planted longleaf stands in the region (e.g., extended grassland stage, dependency on prescribed fire, slower growth rate on soils suitable for other pine species) compared to other southern yellow pine managed for timber production. If databases allowed, we searched for articles written or translated into English extending to 1950, though few articles were published before 1970 on this topic. Searches in SCOPUS were limited to articles after 1960. We also were required to reduce the number of search terms in SCOPUS due to term limits per search set (Table S1). Searches in Elsevier Science Direct were limited to eight Boolean operators, so we broadened search terms and considered results from this search as supplemental to the main searches in Web of Science and SCOPUS. We discovered that several papers in the Southeastern Association of Fish and Wildlife Agencies (SEAFWA) annual conference proceedings series (www.seafwa.org/publications / proceedings; accessed on 4 October 2020) were not identified in database searches. As SEAFWA proceedings are a peer-reviewed publication outlet, we performed a secondary screening on the conference proceeding site for the term "pine" and "bird" or "avian" to incorporate SEAFWA proceedings into the review process. To be comprehensive, we also conducted a supplemental search in Google Scholar using terms described in Table S1. As Google Scholar advanced searches were too restrictive in title only searches, we searched full-text articles, which returned approximately 14,000 records. To reduce screening time, we sorted results by relevance and manually screened the top $5 \%$ of records to be added into an online library and later imported into our reference management software.

We allowed for inclusion of articles published in peer-reviewed literature, published books, technical reports, conference proceedings, and theses and dissertations, but excluded conference abstracts and popular articles. We used a combination of Mendeley citation management software web extension capabilities to extract citations from web searches and Rayyan systematic review software [23] to organize, screen, and label citations for inclusion and exclusion, and by topic area. Once we imported citations into Rayyan, we used the PRISMA framework to 
1. conduct an initial automated duplicate detection process to eliminate duplicates;

2. screen title and abstract content for relevancy; and

3. complete a second full-text screen of all relevant records for inclusion decisions.

We made exclusion decisions for duplicates not identified by automated screening, irrelevant publications (e.g., outside geographic extent, no bird component, etc.), or relevant publications that were from studies conducted in southeastern pine systems but on state, federal or reserve lands. We excluded publications from public lands because planted stands on publicly owned lands are generally not subjected to the same silvicultural management regimes as privately-owned, managed forests, are embedded in different landscape contexts, and managed under widely varying missions and forest management objectives. For example, native pine systems managed by the U.S. Department of Agriculture (e.g., U.S. Forest Service), U.S. Department of Interior (e.g., National Wildlife Refuge System), or state systems of protected lands (e.g., state parks) often have varying missions to sustain health and productivity of forest systems, sustain trust fish and wildlife resources, or enhance public access to the outdoors. Under these varying missions, native pine stands on public lands are often managed under forest prescriptions that are less intensive, including longer rotations, lower basal areas, uneven-aged management, and potentially more frequent intermediate management practices. We also excluded all theses or dissertations, or components therein, that were published elsewhere in primary literature. For articles marked for inclusion in Rayyan, we assigned labels indicating biodiversity, biofuels management, breeding, coarse-woody debris (CWD), cutover, early successional pine, fire, grazing, herbicide, landscape associations, late rotation, mid-rotation, mowing, nest success, pine-hardwood, private [non-industrial] pine, regeneration, roller chopping, streamside management zone (SMZ), select cutting, short rotation, simulation, snag retention, stand establishment, thinning, tree density, or winter. This allowed for better organization of review content under general forest management and population survey themes.

\section{Results}

We identified 160 records through primary database searches and 1696 secondary records from supplemental searches and other sources. After removing duplicates, we screened 1776 records via title and abstract screening, followed by a full-text assessment of records that passed the initial screening process. We also evaluated 42 theses and dissertations. We identified 103 relevant articles for inclusion in review results ranging from 1956 to 2020 (Table S2). We identified 67 studies that evaluated avian population associations with managed pine systems during the breeding season, and 15 studies that incorporated avian surveys during winter, 11 of which incorporated breeding and winter survey components. Note that in many instances, multiple topic areas (i.e., tags) were assigned to a single publication that incorporated evaluation of avian associations with different management practices, across seasons, or for a variety of forest stand ages/conditions. Therefore, numbers of studies listed below are not necessarily mutually exclusive.

The number of publications focused on avian community associations with private, managed pine systems increased substantially from the 1970's through the early 2000's (Figure 2). This shift is likely concomitant to the conversion of land to managed pine across the Southeast during the late 1960's-mid 1970's, and a shift in research focus from game species to more of a biodiversity context during this time. Most publications in our review results evaluated avian population and community associations with young stand ages $(n=41)$, followed by stand establishment or management at intermediate (mid-rotation) ages $(n=23$ each), and studies evaluating late rotation $(n=12)$. Regarding forest management practices, we found that publications assessing herbicide (as part of standestablishment or mid-rotation management) were most common $(n=24)$, followed by publications assessing prescribed fire $(n=15)$, forest thinning $(n=11)$, and forest clearcut at the end of stand rotation $(n=12)$. We also found 14 publications that evaluated avian 
associations with landscape features and three that used simulation models to evaluate avian associations with forest management. We found 11 publications that evaluated SMZs, 10 that evaluated forest biofuels, and nine that evaluated snag retention or CWD. We also found 11 publications that incorporated components of pine-hardwood in their assessment and seven studies that had components of non-industrial, private tree plantations incorporated. The remaining topic areas (e.g., forest regeneration, nest success, select cutting, mowing, roller-chopping, short rotation, tree density and grazing) each had less than five publications found during the review, with the least number of publications on short-rotation, roller chopping, grazing, and tree density. The reduced number of publications relevant to these topic areas may result from a combination of shifting forest management away from these practices over time and/or limited research interest on these topic areas.

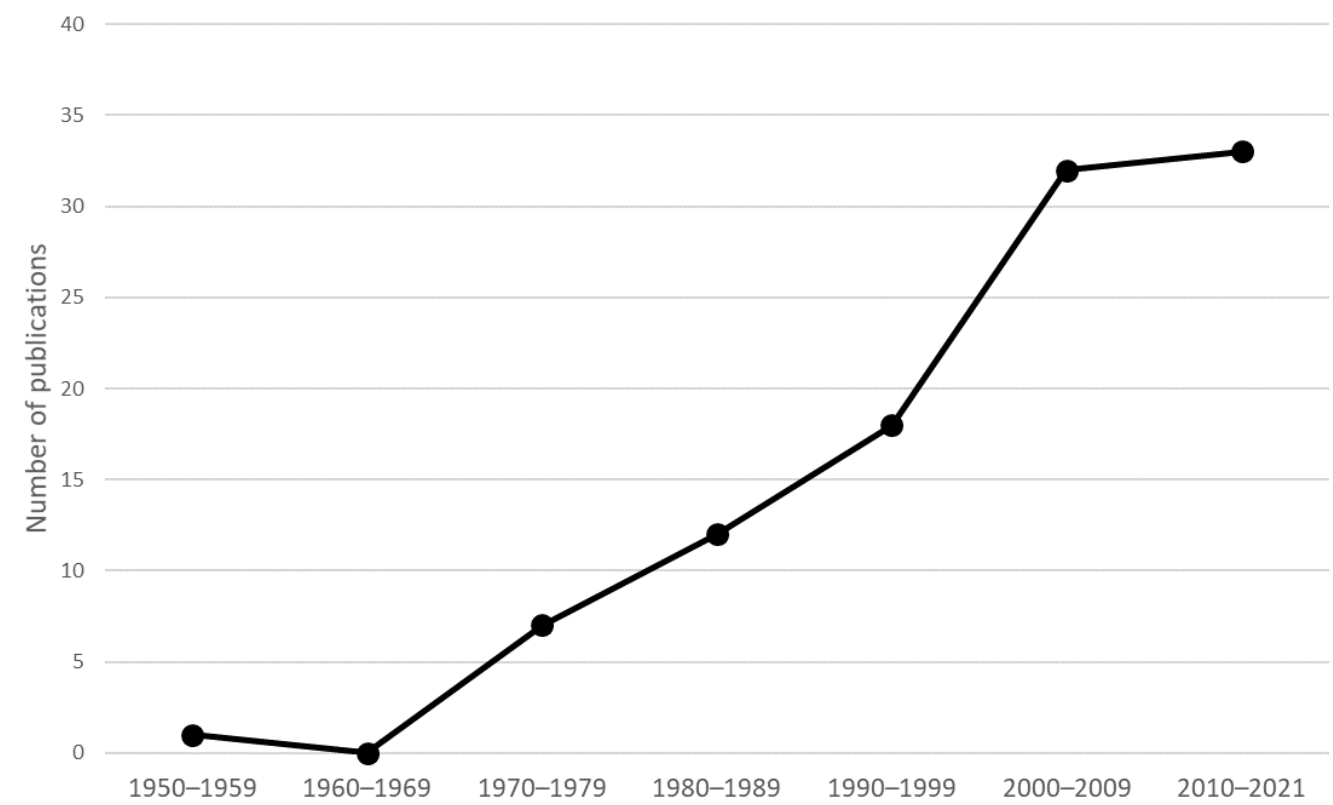

Figure 2. Number of publications focusing on avian community associations with southeastern managed pine systems, categorized in decadal increments (1950-2021).

In summarizing only publications in the last 26 years (1995-2021), we found estimates of avian species richness varied across studies but suggested, on average, 51.53 (SD 23.62; range 11-113) species during the breeding season and 37.25 (SD 11.86; range 22-52) species during winter were observed in managed pine systems landscapes, representing a range of avian communities (Figure 3 ). Outliers in measures of species richness identified in Figure 3 during breeding season studies ( $n=104$ and 113 species) reflected landscape-level research that characterized numerous watersheds or sampling areas, often capturing non-pine system elements incorporated into the managed pine landscape. These publications represented nine southeastern states, focused primarily on loblolly pine systems during the breeding season, and evaluated management practices related to stand establishment, stand age, intermediate management, coarse- and meso-filter practices, and biofuels (Table 2). 


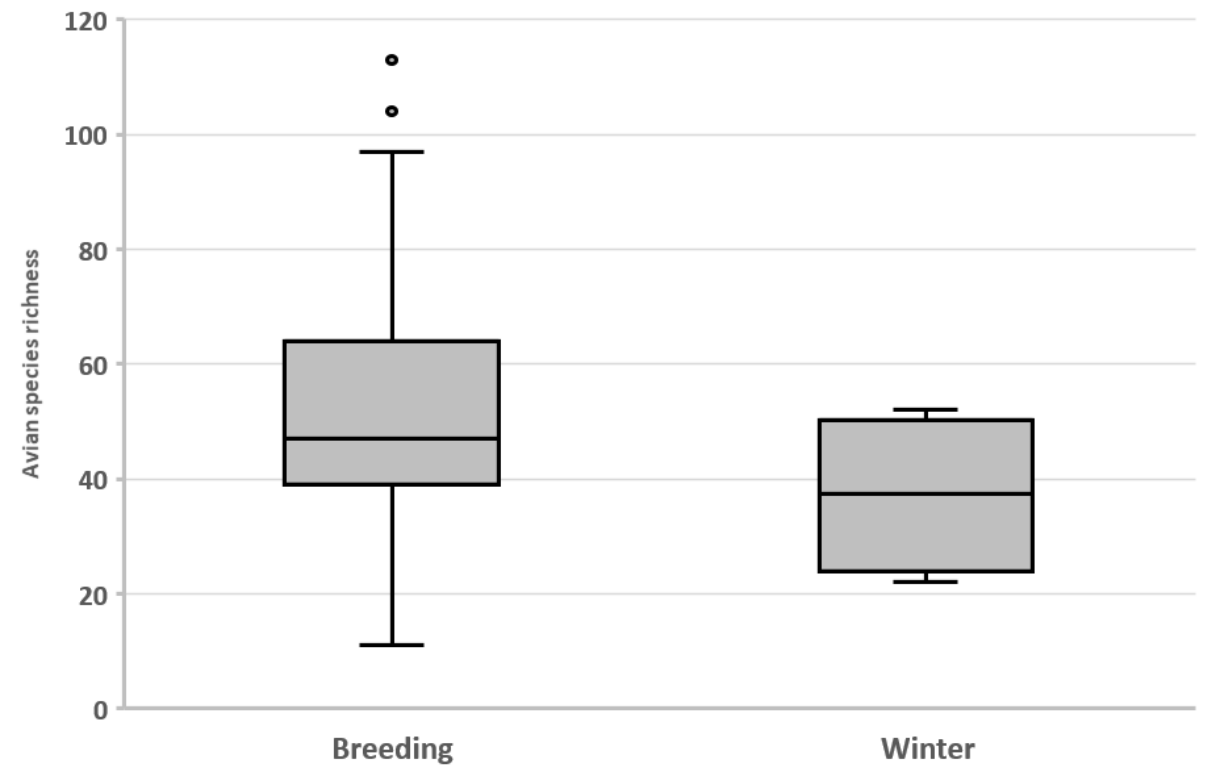

Figure 3. Box and whisker plot of avian species richness during breeding season and winter in managed pine systems across 29 publications in nine southeastern states (1996-2021). The center line represents median species richness, gray box represents interquartile range, whiskers represent range, and points represent outliers in the datasets.

Table 2. Summary of avian species richness quantified by studies conducted on southeastern managed pine landscapes subjected to a variety of conventional management practices during since the beginning of SFI and FSC forestry standards (1996-2021).

\begin{tabular}{|c|c|c|c|c|c|}
\hline $\begin{array}{l}\text { Management } \\
\text { Condition } \\
\text { Evaluated }\end{array}$ & State & Pine System & Season & $\begin{array}{c}\text { Species } \\
\text { Richness }\end{array}$ & Reference \\
\hline \multirow{4}{*}{$\begin{array}{c}\text { Stand } \\
\text { establishment }\end{array}$} & GA & Loblolly & $\begin{array}{l}\text { Breeding } \\
\text { Winter }\end{array}$ & $\begin{array}{c}18-39 \\
30\end{array}$ & $\begin{array}{c}{[24,25]} \\
{[24]}\end{array}$ \\
\hline & LA & Loblolly & Breeding & $49-56$ & {$[26,27]$} \\
\hline & MS & Loblolly & $\begin{array}{l}\text { Breeding } \\
\text { Winter }\end{array}$ & $\begin{array}{c}24-38 \\
45\end{array}$ & {$[28-30]$} \\
\hline & NC & Loblolly & Breeding & $34-76$ & {$[32,33]$} \\
\hline \multirow{7}{*}{ Stand age } & \multirow{2}{*}{ LA } & Loblolly (4-23 years) & Breeding & 44 & [34] \\
\hline & & Slash (1-2, 6-7 years) & Breeding & $45-47$ & [35] \\
\hline & \multirow{3}{*}{ MS } & Loblolly $(<3,>15$ years $)$ & Breeding & $58-63$ & [36] \\
\hline & & $\begin{array}{c}\text { Loblolly } \\
\text { ( }<3 \text { to }>6 \text { years post-thin) }\end{array}$ & Breeding & 68 & [35] \\
\hline & & Loblolly ( $<5->15$ years) & Breeding & $39-43$ & [37] \\
\hline & NC & \multirow{2}{*}{$\begin{array}{l}\text { Loblolly (1-29 years) } \\
\text { Loblolly, Shortleaf } \\
\text { (2-16 years) }\end{array}$} & Breeding & 68 & [38] \\
\hline & $\mathrm{TX}$ & & Winter & 22 & [39] \\
\hline $\begin{array}{c}\text { Uneven-/ } \\
\text { Even-aged } \\
\text { management }\end{array}$ & $\mathrm{TX}$ & Loblolly, Shortleaf & Breeding & $11-25$ & [40] \\
\hline \multirow{2}{*}{$\begin{array}{l}\text { Intermediate } \\
\text { management }\end{array}$} & FL & Slash & Breeding & $39-52$ & [41] \\
\hline & MS & Loblolly & Breeding & 64 & [42] \\
\hline \multirow{3}{*}{ Coarse filter } & AR & Loblolly, Shortleaf & Breeding & 97 & [43] \\
\hline & SC & Loblolly & Breeding & 113 & [44] \\
\hline & AR, LA & Loblolly, Shortleaf & Breeding & 104 & [45] \\
\hline \multirow{3}{*}{ Meso-filter } & $\mathrm{GA}, \mathrm{NC}$ & \multirow{3}{*}{ Loblolly } & Breeding & $40-63$ & [46] \\
\hline & NC & & Winter & 52 & [47] \\
\hline & 10 & & Breeding & $37-53$ & {$[48,49]$} \\
\hline \multirow{2}{*}{ Biofuels } & $\begin{array}{l}\text { AL, FL, } \\
\text { GA }\end{array}$ & Loblolly, Slash & Breeding & 81 & {$[50]$} \\
\hline & MS & Loblolly & Breeding & 39 & [51] \\
\hline
\end{tabular}




\section{Discussion}

Results from our systematic review suggest southeastern managed pine landscapes contribute to diversity and abundance of a variety of early successional, shrubland, and mature forest bird communities. Our review also suggests that effects of managed pine systems on avian communities largely depend on the type of vegetative cover replaced, tree species planted, management regime, and set-aside components within the larger landscape (Figure 4). The management regime, specifically, strongly influences the diversity of vegetative communities in planted stands to which avian species directly respond. Below, we summarize aspects of forest management that may disproportionately affect resources available to avian communities at local- and landscape-scales in managed pine landscapes in the Southeast. Further, we identify important knowledge and application gaps that, if addressed, may further enhance value of these forest systems to avian communities.

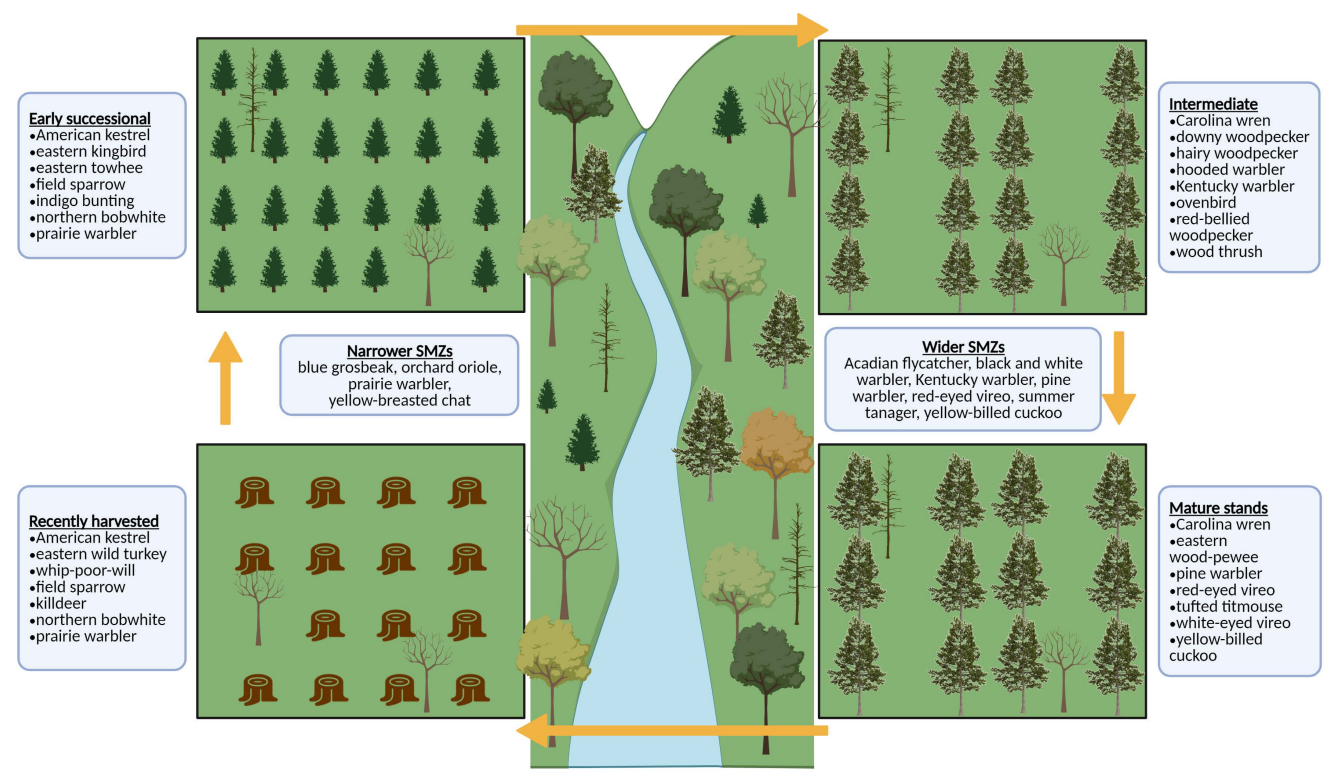

Figure 4. Schematic summarizing a sample of species typical of avian communities associated with recently harvested, early successional, intermediate, and mature managed pine stands, and narrow and wide streamside management zones (SMZs) in southeastern managed pine landscapes. Created with BioRender.com (accessed on 4 October 2020).

\subsection{Birds in Managed Pine Landscapes at Early Successional Stages}

A recent assessment of long-term population changes suggests grassland birds have experienced the steepest declines of all North American breeding bird guilds, with $74 \%$ of grassland species in decline [20]. Shrubland birds have experienced similar declines but are often overlooked [52]. Biodiversity contributions of early successional stages of managed pine are often not considered with respect to their contributions to early successional and shrubland bird communities [53]. Though ephemeral in nature, managed pine stands support disturbance-dependent grassland and scrub-successional bird communities during regeneration stages $[24,26,28,31,34]$. These post-disturbance forests are often high in species diversity as there is ample light available to support diverse vegetative conditions $[26,28-32,53]$. Estimates of species richness suggest up to 76 native bird species detected in pine stands in the region from 1-5 years' post-establishment ([26,32,33,36,47]; Table 1). Up to 70\% of species found in young pine stands are considered early successional/disturbancedependent species [47], with many being species of conservation concern/priority (e.g., American kestrel (Falco sparverius, Linnaeus, 1758), eastern kingbird (Tyrannus tyrannus, Linnaeus, 1758), eastern towhee (Pipilo erythrophthalmus, Linnaeus, 1758), field sparrow (Spizella pusilla, A. Wilson, 1810), northern bobwhite (Colinus virginianus, Linnaeus, 1758), prairie warbler (Setophaga discolor, Vieillot, 1809)) [26,34,36,38,47]. 
Young pine stands are subject to rapid vegetative succession and may approach canopy closure in just a few years following establishment, depending on silvicultural regime (e.g., site preparation intensity, herbaceous control, hardwood control, row-spacing, intercropping, etc.) and site index. Bird communities requiring early successional vegetative structure tend to exhibit increasing species richness and abundance in managed pine stands from about $1-2$ years to $5-8$ years, then decline as canopy closure ensues [26,29,32,34,37,47,54-59]. An exception is the Swainson's warbler (Limnothlypis swainsonii, Audubon, 1834), a species of high conservation concern, which makes use of the high foliage density often present in young, closed-canopy pine stands prior to pre-commercial thinning [60-64]. Prairie warblers also tend to be more tolerant of early stages of canopy closure and can often remain in a stand through 11 years of age [38]. Given the abrupt changes in vegetation conditions, managed pine stands are characterized by rapid turnover of avian communities, with shifting costs and benefits to species over time among approximately $6-8$ year windows $[19,38,56]$.

There is also evidence that intensity of stand establishment practices substantially affects early successional avian communities in managed pine stands. Practices of greater intensity that significantly reduce vegetative cover after establishment negatively influence avian communities within the first few years following application $[29,31,54,65,66]$. Low intensity mechanical or chemical-only site preparation methods consistently exhibited greater densities and richness of avian species in the first 6-8 years after stand establishment $[29,32,33,67]$. Using prescribed fire to reduce harvest residues during site preparation is also a common practice $[34,65,68]$, and significantly increases avian richness by the second year following application [27]. However, methods that combine mechanical and chemical site preparation practices tend to negatively affect avian communities, particularly for open-canopy, ground-shrub, and neotropical migratory species [69]. Herbaceous weed control (HWC) following planting is another common stand establishment practice and results in variable, but generally ephemeral, effects on avian communities [28-31]. Again, more intensive chemical HWC (broadcast vs. banded control) generally results in negative effects on breeding and overwintering bird communities [28,30,31]. Banded HWC applications combined with low-intensity site preparation practices may improve avian diversity compared to lesser-used broadcast applications [28,30,34]. Thus, limited site preparation and intensity of HWC, when practicable, is important for maintaining or promoting avian diversity in young managed pine stands $[16,69,70]$. However, managers must be parsimonious in investments into stand establishment as those costs will be carried through the rotation and realized at final harvest. Judicious use of stand establishment practices to minimize costs for ensuring successful regeneration likely contributes to conservation value of managed pine systems as this encourages moderation of treatment intensity and evaluations of cost:benefit ratios among treatment options integrating conservation value and economic return on investments.

\subsection{Effects of Intermediate Forest Management on Bird Communities}

Nearly all commercial timber production systems in the Southeast implement some form of intermediate (or, mid-rotation) management to optimize timber value. Intermediate management improves habitat availability for birds in managed pine systems as open canopies promote more complex understory vegetative structure $[4,5,16,70,71]$. Reducing forest basal area through thinning is often used in combination with herbicide application to control woody competition. Prescribed fire is another consideration, when possible, to reduce woody cover and promote herbaceous understory cover. In general, reduction of stand basal area, combined with a diversity of management practices applied periodically, provide some of the greatest increases in species richness and abundance (compared to un-thinned, unmanaged stands) within managed pine landscapes and provides managers with flexibility to manipulate stand conditions for multiple species. Comparisons among thinned, unthinned, and early successional managed pine stands generally suggest greater avian species richness and abundance in thinned stands $[34,38,48,50,72,73]$. 
Increases in bird richness tend to occur immediately following first and second thinnings and continue for as much as six or more years [48]. However, there are few studies that have evaluated longer-term effects of forest thinning on wildlife communities. Effects of forest thinning may also be influenced by factors linked to original planting density and/or row spacing. Row-spacing influences bird communities within the first years after establishment $[26,32,33]$, and simulation analysis shows that initial planting density is a primary driver of open canopy conditions and associated species (e.g., gopher tortoise (Gopherus Polyphemus, Daudin, 1801)) throughout a forest rotation [59]. However, information regarding effects of initial planting density following forest thinning is limited.

Forest thinning benefits multiple species guilds, with observed increases in forest canopy, early successional ground-dwelling, and cavity-nesting species following thinnings [34]. Thinning generally results in increased abundance of mature forest species such as red-eyed vireo (Vireo olivaceus, Linnaeus, 1766), eastern wood-pewee (Contopus virens, Linnaeus, 1766), pine warbler (Setophaga pinus, Linnaeus, 1766), tufted titmouse (Baeolophus bicolor, Linnaeus, 1766), summer tanager (Piranga rubra, Linnaeus, 1758), brown-headed nuthatch (Sitta pusilla, Latham, 1790), and Carolina wren (Thryothorus ludovicianus, Latham, 1790) $[34,38,72-74]$. Decreased canopy cover following thinning allows for development of understory vegetation, often resulting in increases of forest shrub and midstory-dependent species, such as wood thrush (Hylocichla mustelina, Gmelin, 1789), hooded warbler (Setophaga citrina, Boddaert, 1783), and Kentucky warbler (Geothlypis formosa, A. Wilson, 1811). Ground-nesting, mature forest species, such as worm-eating warbler (Helmitheros vermivorum, J.F. Gmelin, 1789) and ovenbird (Seiurus aurocapilla, Linnaeus, 1766), also exhibit peak abundances post-thinning [73], though worm-eating warbler exhibited negative response to thinning in one study [72]. Early successional species, such as indigo bunting (Passerina cyanea, Linnaeus, 1766), prairie warbler, and common yellowthroat (Geothlypis trichas, Linnaeus, 1766) also respond well to post-thinned conditions during the breeding season $[34,73]$. Several wintering species prefer thinned pine stands including eastern phoebe (Sayornis phoebe, Linnaeus, 1766), hermit thrush (Catharus guttatus, Pallas, 1811), golden-crowned kinglet (Regulus satrapa, Lichtenstein, 1823), and ruby-crowned kinglet (Regulus calendula, Linnaeus, 1766) [72,73,75]. However, birds dependent on thick scrubby conditions, such as Swainson's warbler, American redstart (Setophaga ruticilla, Linnaeus, 1758), gray catbird (Dumetella carolinensis, Linnaeus, 1766), white-eyed vireo (Vireo griseus, Boddaert, 1783), yellow-breasted chat (Icteria virens, Linnaeus, 1758), and brown thrasher (Toxostoma rufum, Linnaeus, 1758), tend to exhibit lower occurrence rates post-thinning during the breeding season compared to pre-commercial thinning when canopies are closed [34]. Studies also showed that cavity nesting species either inhabited pine stands only after thinning (e.g., red-bellied woodpecker (Melanerpes carolinus, Linnaeus, 1758), pileated woodpecker (Dryocopus pileatus, Linnaeus, 1758) [38]), or more than doubled in density (e.g., downy woodpecker (Picoides pubescens, Linnaeus, 1766), hairy woodpecker (Picoides villosus, Linnaeus, 1766) [38], red-bellied woodpecker [34]) following thinning (but see null effects of forest thinning in [49]).

Though thinning alone is preferred to unthinned forest to improve conservation value of managed pine stands for birds, thinning used in combination with management practices that promote diverse herbaceous understories may be optimal for bird communities. Fire is of particular interest in managed pine stands because it can stimulate vegetative conditions necessary for species associated with pine-grassland systems [19]. However, fire is a challenge to implement in managed pine landscapes due to myriad reasons, including concerns related to weather variability, capacity, public opinion, air-quality/smoke management, and liability $[76,77]$. Temporal and spatial scales of prescribed fire applications are also a concern, as large, uniform, and frequently burned fire blocks may reduce the ability for individuals to seek appropriate refugia in the near-term following fire disturbance [70,77]. Several species demonstrating preference for pine-grasslands are widely known to respond favorably to fire in pine systems-including red-cockaded woodpecker (Picoides borealis, Vieillot, 1809), Bachman's sparrow (Peucaea aestivalis, Lichtenstein, 1823), Henslow's spar- 
row (Ammodramus henslowii, Audubon, 1829), northern bobwhite, and eastern wild turkey (Meleagris gallopavo, Linnaeus, 1758) [78-83]. However, these studies examined response to fire on non-commercial forest as research on species' response to fire on managed pine landscapes is limited to a few studies (cited herein). Other species are known to respond well to low-moderate or sometimes even high severity fire on the landscape including red-headed woodpecker (Melanerpes erythrocephalus, Linnaeus, 1758), hairy woodpecker, eastern woodpewee, eastern kingbird, eastern bluebird (Sialia sialis, Linnaeus, 1758), prairie warbler, brown-headed nuthatch, chipping sparrow (Spizella passerine, Bechstein, 1798), and field sparrow [80]. Seasonality of fire may also have variable effects on bird communities as species respond to shifts in post-fire vegetative conditions. Dormant season fire following thinning increases breeding bird abundances relative to thinned, unburned sites [42,84]. However, dormant-season fire may also have short-term negative effects on overwintering bird species [41]. Growing season fire positively affects overwintering and breeding bird richness and abundance of Bachman's sparrow, Henslow's sparrow, northern bobwhite, brown-headed nuthatch, and other species [41,79].

Bird communities respond variably to combination applications of prescribed fire and herbicide for hardwood understory control following forest thinning [42,69,75,84-86]. As expected, there is a response lag following fire and herbicide treatments as vegetative communities recover post-disturbance $[75,86]$. However, species begin to respond rapidly after 2-3 years following treatments of a single, selective herbicide, followed by repeated prescribed fires within 6 years after treatment $[42,85]$. In general, species preferring early succession and/or pine-grassland vegetative structure tend to do well following combination treatments $[42,84-86]$. Species such as eastern wood-pewee, yellow-throated warbler (Setophaga dominica Linnaeus, 1766), eastern towhee, northern bobwhite, common yellowthroat, indigo bunting, and yellow-breasted chat respond positively to combination burn and herbicide management $[42,84,86]$. Other species, such as prairie warbler, respond variably across years as succession proceeds following disturbance [42]. Combinations of prescribed fire and herbicide are also known to exhibit the greatest avian conservation values (total and early succession/pine grassland) when compared to single treatments or unmanaged stands $[42,84,86]$. This suggests that disturbance-dependent species of high conservation priority preferring open canopy pine systems likely benefit the most from these practices. However, in the event combination methods are impracticable, independent application of prescribed fire or herbicide would likely result in greater bird richness and abundance than stands with no intermediate management following thinning [42].

Not all species will be maintained in stands subjected to intermediate management practices such as prescribed fire and herbicide. Instead, each intermediate management practice is known to produce a unique set of vegetative conditions that favor subsets of the avian community, including conditions that arise when no management is applied [42]. Species such as wood thrush, Kentucky warbler, and hooded warbler exhibit reduced abundance in areas treated with intermediate management. This is particularly the case in response to combination management such as single application herbicide followed by prescribed fire $[42,75,84-86]$. Other species requiring some level of shrubby understory such as white-eyed vireo, northern cardinal (Cardinalis cardinalis, Linnaeus, 1758), and bluegray gnatcatcher (Polioptila caerulea, Linnaeus, 1766) also exhibit lower levels of abundance when combination treatments are applied $[42,75,84-86]$. Moreover, there is some evidence that bark gleaning species typically not associated with a shrubby understory, such as black and white warbler (Mniotilta varia, Linnaeus, 1766), and tufted titmouse, are reduced in abundance on sites treated with combination management practices $[42,75,85]$. Prescribed fire alone, even moderate-low intensity, can significantly affect species such as Acadian flycatcher (Empidonax virescens, Vieillot, 1818), great-crested flycatcher, red-eyed vireo, wood thrush, and hooded warbler in southeastern managed pine systems [80]. Yellowbilled cuckoo, ovenbird, and several warbler species (worm-eating, Kentucky, black and white, hooded) show strong negative responses to low-moderate fire severity on the landscape [80]. Thus, rather than recommendations for a single management practice, it is 
the variety of management practices across managed pine landscapes that will benefit the most species [42].

\subsection{Species Requiring Special Management}

Despite planting native pine species and improvements in sustainable forest management practices over time, conventional silvicultural practices in managed pine landscapes remain incompatible with conservation of some species. Therefore, identifying opportunities to provide necessary vegetative structure for these species may be critical to their conservation. However, it is important to note that surrounding land uses also provide structure required for several bird species that are not likely to be supported in managed forests, no matter how they are managed. A useful framework is to consider avian response to pine management at coarse- and fine-filter levels [87]. At the coarse-filter level, most avian species can be accommodated on managed pine landscapes when a diversity of stand types and landscape configurations are present [43]. However, some species with specialized needs may not be accommodated without specific management actions (i.e., fine-filter).

Though they have been documented in managed pine stands, bird species that are mostly reliant on fine-filter management (e.g., heavy thinning to reduce forest basal area and frequent prescribed fire to maintain herbaceous understory cover) are generally low in abundance under standard management practices [88-90]. An example of such a finefilter species is the red-cockaded woodpecker, which inhabits planted pine stands when specific management actions are taken (e.g., frequent fire, longer rotations, provision of artificial cavities, etc.). Bachman's sparrow and Henslow's sparrow are other examples of species that are readily maintained in managed pine landscapes if fine-filter management approaches are taken, such as thinning followed by frequent (e.g., 3-year fire return interval) prescribed fire or other hardwood control treatments (e.g., herbicide application alone or in combination with prescribed fire) $[50,84,88,89,91]$. Private forest landowners may intentionally manage areas to meet species' habitat requirements through mechanisms such as Safe Harbor Agreements to reduce or eliminate regulatory burdens across the broader landscape $[92,93]$.

Other species of lesser conservation concern are widely associated with mature pine forests and may exhibit reduced abundances in stands managed with shorter rotations. Very early work showed species such as pine warbler, Carolina wren, eastern wood-pewee, tufted titmouse, and others could be found in greater densities in 60- and 100-year-old pine stands compared to younger stands representative of contemporary rotations [94]. Similarly, densities of these species, plus others such as red- and white-eyed vireo, yellowbilled cuckoo (Coccyzus americanus, Linnaeus, 1758), summer tanager, Carolina chickadee (Poecile carolinensis, Audubon, 1834), and great-crested flycatcher (Myiarchus crinitus, Linnaeus, 1758) were greater on mature mixed-pine hardwood stands in the early days of establishing planted pine $[95,96]$. Overwintering species such as yellow-rumped warbler, ruby- and golden-crowned kinglet, white-throated sparrow (Zonotrichia albicollis, Gmelin, 1789), hermit thrush, and others also tended to exhibit substantially greater densities in mature mixed-pine hardwood stands [95]. Moreover, these effects have been demonstrated at a watershed-scale, whereby watersheds primarily composed of natural mixed-pine hardwoods showed greater densities of species such as pileated woodpecker and pine warbler compared to watersheds dominated by managed pine stands, despite the fact that managed pine landscapes exhibited greater levels of avian diversity [43].

As expected, species typical of oak-hickory hardwood forests were also historically found in much greater densities in older (>150-year-old) hardwood forest stands compared to mature and young pine stands [94]. Though often occurring in mature pine stands, species of conservation concern such as yellow-billed cuckoo and wood thrush, and other species such as red-eyed vireo, were more abundant in mature hardwood forests compared to mature and young pine [94]. Other species were historically shown to exclusively occur in hardwood systems, including black and white warbler, Kentucky warbler, and Acadian 
flycatcher [94]. Many of these species now regularly inhabit riparian hardwood stands within managed pine landscapes, but generally at lower abundances than historically documented. However, some species that require very different vegetative conditions than managed pine stands can provide are rarely detected in southeastern managed pine forests such as yellow-bellied sapsucker (Sphyrapicus varius, Linnaeus, 1766), American redstart, northern parula (Setophaga americana, Linnaeus, 1758), prothonotary warbler (Protonotaria citrea, Boddaert, 1783), and Louisiana waterthrush (Parkesia motacilla, Vieillot, 1809) [95]. These species are common in surrounding areas such as forested wetlands, natural mixedpine hardwoods, and upland hardwoods in the region and not necessarily species of conservation concern for managed pine systems to compensate. However, worm-eating warbler presents a special case where the species is generally assumed to inhabit mature hardwood and mixed-pine hardwood forest systems. It is suspected that the species is more of a generalist than previously thought and can be found regularly in managed pine stands following canopy closure [97]. Worm-eating warbler and Swainson's warbler using closed-canopy, pre-thinned pine forests certainly warrant continued investigation, particularly to determine reproductive success in young stands relative to success in other forest conditions (e.g., [61]). If these species are able to successfully reproduce in young, closed-canopy pine stands, this may represent a greater level of adaptive behavioral plasticity than previously assumed, and suggests conservation value of managed pine systems for these species.

Although fine-filter management strategies benefit some additional species, these strategies are not always feasible to implement. Some species readily adapt to managed pine conditions. Other species can persist at lower abundances in managed pine landscapes or may use these areas as temporary refugia, migratory stopover points, or dispersal corridors. More work is needed to understand potential conservation value of the latter two scenarios, and it is important to continue to strive toward understanding the balance of conservation contributions and limitations of managed pine systems within the larger landscape context. This improved understanding can aid forest managers in developing and refining strategies to facilitate conservation of birds within the realities of private forest objectives. Similar to natural forests, no single forest condition will suffice to meet the life history requirements of all bird species [42].

\subsection{Meso- and Fine-Filter Management Approaches to Retain Key Structures for Bird Species}

Retention of hardwood or mixed pine-hardwood riparian cover (e.g., stringers, SMZs), $\mathrm{CWD}$, and snags are meso- and fine-filter management approaches by which a greater diversity of avian species may be maintained in managed pine landscapes. Maintaining mature forest cover adjacent to hydrologic features is common in most forest harvest operations as part of forestry best management practices (BMPs) for water quality protection $[37,45,98-100]$. For example, SMZs and stringers represent, on average, $17.4 \%$ of a management unit's area in the South-Central Plains ecoregion. However, these areas contribute to $27 \%$ of avian species diversity [45]. Stringers and SMZs introduce heterogeneity in cover types and are widely known to provide food and cover resources absent in adjacent stands, and movement corridors for a variety of wildlife taxa, in addition to providing hydrologic benefits within forested systems $[45,101]$. Substantial hardwood overstory cover in SMZs often contains species such as yellow-billed cuckoo, Acadian flycatcher, and pileated woodpecker [100]. However, the value of cover provided by SMZs to avian communities often varies by SMZ width. Narrow SMZs tend to support more early successional and shrubland bird species and wider SMZs generally support bird species more commonly found in interior hardwood forest systems [98-100]. Studies of SMZ width sometimes, but not always, show greater bird abundances with increasing width, though that may not hold true for measures of avian richness or occupancy $[99,100,102]$. Yellow-billed cuckoo, Kentucky warbler, black and white warbler, red-eyed vireo, Acadian flycatcher, summer tanager, pine warbler, and several other species exhibit greater abundances in wider SMZs $[98,100,102]$. Species such as yellow-billed cuckoo, Acadian flycatcher, yellow- 
throated vireo, and pileated woodpecker have been suggested to require or have greatest abundance in SMZs greater than $60 \mathrm{~m}$ in width in managed pine landscapes [100,102]. In contrast, species favoring shrubland vegetative structure, such as yellow-breasted chat, orchard oriole (Icterus spurius, Linnaeus, 1766), blue grosbeak (Passerina caerulea, Linnaeus, 1758), prairie warbler, and others tend to exhibit greater abundances in narrower SMZ widths $[98,100,102]$. Increasing SMZ width may reduce perceived linearity of SMZ patches for area- or edge-sensitive species, with an SMZ becoming more of a forest patch than a narrow corridor as width increases. A recent study found SMZs are generally wider than required by forestry BMPs, thus providing greater value for biodiversity [45]. However, more research is needed regarding optimum SMZ width to meet timber production goals while providing conservation value. However, corridor/dispersal functions provided by SMZs in managed pine landscapes remain poorly understood.

Other set-aside areas, such as unique ecological sites or communities, may also provide important meso-filter components. Reserved areas of conservation importance such as hardwood coves, wet-pine savannas, and other wetlands, harbor several bird species of conservation value not typically prevalent in managed pine systems [37]. Simulation studies that allow for mature pine and hardwood set-aside scenarios also demonstrate species richness benefits for overall bird communities, and for neotropical migrant, cavitynesting, and scrub-successional bird species $[103,104]$. Some species respond favorably to retained ecologically important communities including Acadian flycatcher, blue-gray gnatcatcher, and common yellowthroat [103]. However, set-asides come at the expense of up to $14-100 \%$ of harvested wood volume (depending on set-aside regime) [103], which may make implementation a challenge in managed pine landscapes. Furthermore, conservation of sensitive or unique ecological communities is required under forest certification programs, providing an additional incentive to maintain sites that may contain high conservation value.

Finally, there has long been interest in the biodiversity effects of retaining standing dead and dying wood (i.e., snags) and CWD as another fine-filter approach to conservation in managed pine landscapes. Dead and decaying organic matter provides resources for countless species, and its decomposition is a critical component of soil accumulation and overall ecosystem integrity $[14,15,105,106]$. Birds, specifically, benefit from dead and dying organic matter as nesting, foraging, and perching resources [15]. Of consequence are associations of cavity nesting bird species with snags in managed forests. Species such as great-crested flycatcher, Carolina chickadee, red-headed, red-bellied, downy, and hairy woodpeckers can be found almost exclusively in stands containing snags [107,108]. Other species respond favorably to snag presence, likely for display and foraging perches, including Carolina wren, brown thrasher, eastern kingbird, eastern towhee, field sparrow, indigo bunting, prairie warbler, and yellow-breasted chat [33]. Comparatively, most managed pine stands have reduced availability of snags and limited organic material on the forest floor, particularly in short-rotation stands with high tree density $[14,105]$. Models of species-habitat relationships have suggested a deficit of snags in southeastern managed pine stands, with one estimate suggesting a $48 \%$ lower prevalence of snags compared to forests on public lands [109]. Even if green trees and/or snags are retained during harvest and stand establishment, rotation ages in most southeastern managed pine stands prohibit trees from naturally senescing, further limiting snag availability [109]. However, green tree and/or snag retention is generally practiced by forest managers within managed pine systems [110]. Additionally, forest certification programs like SFI generally require snag retention following harvest when it is safe to do so, which ensures some availability of standing dead materials for wildlife. Snag retention post-harvest has demonstrable benefits to primary and secondary cavity-nesting species and on overall bird communities in the Southeast $[107,108,111]$. There is also some limited evidence that clustering of snags may benefit cavity-nesting bird communities [112]. Moreover, SMZs, stringers, and other set-asides may provide a valuable source of snags within managed pine landscapes [45]. Though allowing snags to be retained, or allowing existing trees to senesce 
naturally may be contrary to yield objectives, it is plausible that a portion of timber growth could be dedicated to retention of deadwood to help meet sustainability objectives [105]. Empirical studies of avian community associations with CWD on southeastern managed pine stands also suggest that presence of CWD positively affects bird communities in early successional stands $[46,47,50]$. As such, removal of CWD during stand establishment may be detrimental to some avian communities. In one study, nearly $50 \%$ of species analyzed exhibited negative response to woody residue harvest, with the most precipitous negative effects on cavity nesters, bark gleaners, and air salliers [50]. Species-specific accounts [113], and a plethora of existing reviews of CWD benefits to biodiversity suggest potential implications from woody biomass removal both for avian diversity (e.g., [14]) and ecosystem function $[15,105,106,114]$. Thus, decisions to remove or retain CWD as part of stand-level management objectives must be considered in the context of potential effects on avian and other ecological communities.

\subsection{Taking a Landscape Perspective}

Management to conserve a full suite of native bird communities is predicated on the ability to create and sustain a dynamic mosaic of stand conditions across managed pine landscapes beginning with identifying appropriate stand conditions as mentioned. Avian associations with landscape context may be one of the most paramount and least understood issues in southeastern managed pine systems [4]. Frequent disturbances caused by forest management result in landscape patterns that often increase heterogeneity in cover types. The resulting interspersion of different stand ages, types, and sizes/configurations at the landscape-scale may enhance habitat value for many species, provided that excessive fragmentation does not occur [5,115-117]. A heterogeneous forest mosaic that includes managed and unmanaged forest may favor bird species requiring multiple cover types or seral stages for different parts of their life history (e.g., nesting, fledging, foraging, etc.), and/or species with limited dispersal abilities $[7,16,118]$. Heterogeneity may also be an important driver of avian-landscape associations in neotropical and short-distance migrants, and scrub-shrub communities [117,119]. However, high levels of heterogeneity may negatively affect species dependent on larger, contiguous blocks of cover. Area sensitive species, such as wood thrush, exhibit strong positive associations with mature forest area [47]. Care must be taken to understand area requirements of species potentially sensitive to stand size or those that require interior forest conditions (e.g., [56]).

Without the ability to appropriately measure landscape-level effects, simulation models assessing avian response to landscape-level management aids in planning for sustainable forest management scenarios and have been created for southeastern managed pine landscapes for nearly two decades $[103,117,120]$. These models demonstrate that heterogeneity caused by disturbance patterns on managed pine stands may increase avian richness and be positive predictors of bird abundance among forest canopy nesters, scrubnesters, and neotropical migratory species [104,120]. However, extreme levels of fragmentation resulting in small stand sizes (15-25 ha) reduce avian richness, suggesting that negative effects of small patches may outweigh heterogeneity benefits [120]. Several studies have also evaluated breeding bird communities across watersheds to assess variation in forest management strategies at large-landscape scales [43,119,121,122]. Contrary to expectations, studies often show measures of avian abundance and diversity to be greater in watersheds with greater forest management intensity compared to watersheds with greater levels of protected forest [43]. This may be a result of increased heterogeneity of cover types within more intensively managed watersheds [43]. Heterogeneity in managed forest systems results in an abundance of stand adjacencies that may be perceived as edge by some species. Proximity of forest edge increases levels of avian richness, diversity, and abundance as access to light resources allows for increased vegetative complexity [96]. However, adjacency patterns may affect species response to forest edge and/or in associations with edge:area ratio $[35,123]$. Though not evaluated in the Southeast, site productivity may also affect edge 
effects in birds [124]. In addition to associations with heterogeneity in forest age classes, spatial patterns driven by landform may also be a factor for avian communities [36,117].

Scale is a primary factor in determining landscape-level effects of forest management $[44,104,119]$. Significant bird-landscape associations have been detected as distant as $1 \mathrm{~km}$ from a forest stand [119]. In reality, bird associations with features at the localand landscape-level function across multiple scales, with some processes (e.g., nest site selection) being more closely associated with fine-filter resources, and others (e.g., settling decisions) being more closely associated with coarse-filter, landscape-level characteristics $[44,104,116,122]$. Neotropical migrants, such as hooded warbler, northern parula, wood thrush, ovenbird, and yellow-breasted chat are known to exhibit stronger associations with coarse-filter landscape features, whereas American redstart and blue-gray gnatcatcher are known to exhibit stronger associations with fine-filter landscape features $[44,116]$. Determining the most appropriate scale or scales at which birds are responding to managed pine systems remains an important research topic. It is broadly accepted that species perceive a continuum of habitat quality that often supplements or complements species resource requirements within a landscape [5]. However, it is less clear how local- and landscape-level features drive habitat selection preferences of birds, nor at what scale those features operate. It is possible that no single spatial scale will ever be appropriate for assessing avian associations with landscape characteristics [44]. Therefore, it is important that models incorporate explanatory variables measured at both the landscape and local scales to adequately understand species-habitat associations, particularly for migratory bird species or species with very narrow breeding habitat requirements [116].

\subsection{Call to Action to Address Important Knowledge and Application Gaps}

Despite abundant research on a variety of management strategies and stand conditions relative to avian communities, there remain substantial knowledge and application gaps to be addressed in managed pine landscapes. These gaps are often reflective of research questions that are time and/or resource intensive to implement, are limited by availability of technology, and / or are cost-prohibitive to execute. Of foremost importance and similar to other systems, is the paucity of research evaluating population demographics, movement, and associations with surrounding landscape composition and configuration across a variety of scales in managed pine systems. It is critical for the research community to overcome these challenges so that we can more effectively make recommendations for sustainability of a breadth of avian communities within managed pine landscapes in the region and understand the regional contributions of such landscapes to conservation of avian communities. We suggest a shift in research paradigms is needed that remains rooted in ecological theory, and moves the needle forward with respect to resources required for reproduction, survival, and dispersal, as their importance cannot be overstated [125].

Early studies in managed pine landscapes provided anecdotal evidence that birds were nesting successfully, and that there was variation in breeding activity and nest success [65]. We now know that nesting rates vary with intensity of stand establishment practices and intermediate forest management strategies $[44,65,126,127]$. Evidence suggests that managed pine stands may serve as both population sources and sinks depending on several factors, including stand age, distance to forest edge, and stand adjacency $[44,128,129]$. Speciesspecific studies suggest comparable nest densities, nest success, and fledging rates for Swainson's warbler in managed pine vs. bottomland hardwood forests [61], and comparable or greater nesting success in young managed loblolly vs. longleaf pine stands for indigo bunting, northern cardinal, yellow-breasted chat, and prairie warbler [130]. Evidence also suggests that species requiring hardwood components, such as Acadian flycatcher, successfully breed in managed pine landscapes [131]. Stand-scale vegetative structure may play a larger role in nest success than features of the surrounding landscape [44,61]. However, studies assessing reproductive success are few and far between, and some address very specific management questions (e.g., $[126,127,129,132])$. Studies of annual survival are even rarer and require substantial investment in tracking marked individuals to be 
successful [133]. To address these knowledge gaps, we recommend a proactive approach to addressing population demographics as indicators of habitat quality. Research initiatives created via partnerships with forest sustainability programs, bird conservation specialists, forest managers, and researchers that target key deficiencies in demographic knowledge in southeastern managed pine landscapes would greatly improve our understanding of these systems.

Other equally important aspects of avian ecology are all but missing from the literature. Studies of resource selection and other aspects of behavioral ecology in this region are limited in species representation (e.g., eastern wild turkey, Swainson's warbler) $[61,81,128,134]$. Thus, our ability to evaluate resource use sufficiently and empirically (as opposed to resource associations) and behavioral strategies are hampered. We are also challenged to understand higher-order resource selection that may be driving range expansions or contractions and settling responses in managed pine systems (except see [64]). This is particularly important for neotropical migratory birds breeding in these landscapes, and overwintering species selecting features of managed pine forests.

The dynamic mosaic created by forest management may cause species to function as a metapopulation, with periodic local extinctions and re-colonizations sustained through immigration and emigration. Dispersal ability through the managed pine matrix is poorly understood as is landscape fidelity. Except for some game species, we have virtually no understanding of bird movements within managed pine landscapes, nor how meso-filter features of the managed pine landscape (e.g., SMZs) facilitate dispersal and connectivity at the population and genetic level $[14,135]$. There is also ample room to further our understanding of bird responses to heterogeneity introduced by the managed forest mosaic, particularly in further understanding effects of temporal and spatial scale and spatial pattern on different avian communities.

Growing markets for using harvest residue/woody biomass [136,137] are also a potential concern for sustaining biodiversity in the Southeast and an area for future research [138]. Of particular note are potential shifts in forest vegetation structure and successional stage under altered rotations that optimize biomass production while reducing the prevalence of mid-late rotation managed pine on the landscape [138]. However, such a shift in management is not expected to be a primary driver of forest management decisions and demand for wood pellets may maintain or improve ecosystem services from forests [139]. For example, in 2018, biomass from wood pellets comprised only about $3 \%$ of commercial wood harvest [140]. Further, about $20 \%$ of pellet feedstock is from roundwood; the rest is sourced from sawdust and residues from primary lumber processing [138].

Lastly, though we have a well-developed understanding of species response to fire on the southeastern pine landscape, there remains a substantial application gap in the ability to either deliver fire on the ground or determine appropriate fire surrogates in managed pine landscapes. Though area receiving prescribed fire is up $28 \%$ nationally, it has decreased $8 \%$ in the Southeast since 2011 [141]. However, southeastern states, particularly Florida and Georgia, remain national leaders in prescribed fire delivery in forest systems [141]. Overcoming application gaps related to capacity, public perception, and liability concerns in southeastern commercially managed forests remain an important priority as does understanding how alternative management practices can or cannot be used to emulate fire-maintained conditions.

\section{Conclusions}

As many as 6.9 million hectares of the existing 104 million hectares of forested land in the southeastern U.S. are projected to be at high risk for land conversion or loss to rising sea levels by 2060 [13]. Forests managed for economic return are projected to be at lower risk for conversion compared to unmanaged forests and will likely be increasingly relied upon for biodiversity contributions and fiber resources in the future [13]. Managed pine forests in the region will increasingly be in the spotlight to balance economic and biodiversity objectives. Although there is no "recipe" for optimum forest management, practices that involve 
prudent site preparation, promote forest thinning and intermediate management practices, provide non-pine vegetative cover, provide fine- and meso-filter resources, and promote heterogeneity in cover types will enhance the value of southeastern managed pine systems to avian communities. Further, species-level differences in response to management may require prioritization of conservation actions for species sensitive to more intensive forest management, and/or those of conservation concern [142]. However, it is important to emphasize that no single forest type, structure, or age optimizes biodiversity in managed or unmanaged forest landscapes in the southeastern U.S. [70]. There is general consensus that biodiversity, and particularly avian diversity, is best maintained by producing a diverse mosaic of forest conditions in managed pine landscapes in the region. However, we still lack detailed understanding of critically important factors associated with fundamental avian population processes in forested landscapes, including privately-owned, managed pine landscapes. We recommend a shift in research paradigms to emphasize improved understanding of:

4. bird reproductive success and survival in association with stand structure, spatial configuration, and temporal dynamics;

5. second and third order resource selection, particularly in response to dynamic forest management over time;

6. bird movements within the managed pine matrix, including use of dispersal corridors, gap-crossing abilities, perception of edge, and overall use of a shifting forest landscapes;

7. bird associations with composition and configuration of stands of different age structures, meso-filter components, and influence of temporal and spatial scale on bird communities.

Supplementary Materials: The following are available online at https:/ / www.mdpi.com/article / 10.3390/f12040442/s1, Table S1: Search terms and operators used for systematic literature review of published papers on avian diversity in southeastern managed pine forests (1950-2020); Table S2. Summary of breeding season and overwintering diversity and richness measures across a subset of studies examining avian population response to forest stand types and ages; Access database containing summary of published literature and associated metadata in systematic review results.

Author Contributions: Conceptualization, D.M. and K.O.E.; Methodology, K.O.E., D.M., A.L.-G., C.L.; Software, K.O.E.; Formal Analysis, K.O.E.; Data Curation, K.O.E.; Writing-Original Draft Preparation, K.O.E.; Writing—Review and Editing, K.O.E., D.M., A.L.-G., C.L.; Project Administration, A.L.-G., D.M. All authors have read and agreed to the published version of the manuscript.

Funding: This research was funded by the National Council for Air and Stream Improvement, Inc., Memorandum of Agreement number 21.FE.WB.2, NCASI EW-EWG-2119.

Institutional Review Board Statement: Not applicable.

Informed Consent Statement: Not applicable.

Data Availability Statement: The data presented in this study are openly available in the supplementary MS Access database included with this submission.

Acknowledgments: We appreciate pre-submission reviews provided by J. Verschuyl and R. Iglay and the formal reviews from two anonymous reviewers that improved an earlier version of this manuscript. This manuscript was also produced with support from the Forest and Wildlife Research Center at Mississippi State University.

Conflicts of Interest: The funders approved the original design of the study, assisted in gathering publications, and reviewed/edited the manuscript.

\section{References}

1. Food and Agriculture Organization of the United Nations [FAO]. The State of the World's Biodiversity for Food and Agriculture (2019); Belanger, J., Pilling, D., Eds.; FAO Commission on Genetic Resources for Food and Agriculture: Rome, Italy, 2019. Available online: http:/ / www.fao.org/3/CA3129EN/CA3129EN.pdf (accessed on 4 October 2020). 
2. Food and Agriculture Organization of the United Nations [FAO]. The State of the World's Forests 2020; Food and Agriculture Organization of the United Nations: Rome, Italy, 2020. [CrossRef]

3. Carle, J.; Homgren, P. Wood from planted forests: A global outlook 2005-2030. For. Prod. J. 2008, 58, 6-18.

4. Hartley, M.J. Rationale and methods for conserving biodiversity in plantation forests. For. Ecol. Manag. 2002, 155, 81-95. [CrossRef]

5. Brockerhoff, E.G.; Jactel, H.; Parrotta, J.A.; Quine, C.P.; Sayer, J. Plantation forests and biodiversity: Oxymoron or opportunity? Biodivers. Conserv. 2008, 17, 925-951. [CrossRef]

6. Nájera, A.; Simonetti, J.A. Enhancing avifauna in commercial plantations. Conserv. Biol. 2009, 24, 319-324. [CrossRef] [PubMed]

7. Castaño-Villa, G.J.; Estevez, J.V.; Guevara, G.; Bohada-Murillo, M.; Fontúrbel, F.E. Differential effects of forestry plantations on bird diversity: A global assessment. For. Ecol. Manag. 2019, 440, 202-207. [CrossRef]

8. Shafale, M.P.; Harcombe, P.A. Presettlement vegetation of Hardin County, Texas. Am. Midl. Nat. 1983, 109, 355-366. [CrossRef]

9. Cowell, C.M. Presettlement Piedmont forests: Patterns of composition and disturbance in central Georgia. Ann. Assoc. Am. Geog. 1995, 85, 65-83.

10. Predmore, S.A.; McDaniel, J.; Kush, J.S. Presettlment forests and fire in southern Alabama. Can. J. For. Res. 2007, 37, 1723-1736. [CrossRef]

11. Terrando, A.J.; Costanza, J.; Belyea, C.; Dunn, R.R.; McKerrow, A.; Collazo, J.A. The southern megalopolis: Using the past to predict the future of urban sprawl in the southeast U.S. PLoS ONE 2014, 9, e102261. [CrossRef]

12. Jenkins, C.N.; Van Houtan, K.S.; Pimm, S.L.; Sexton, J.O. US protected lands mismatch biodiversity priorities. Proc. Natl. Acad. Sci. USA 2015, 112, 5081-5086. [CrossRef]

13. Greene, R.E.; Evans, K.O.; Gray, M.T.; Jones-Farrand, D.T.; Wathen, W.G. Using a coproduction approach to map future forest retention likelihood in the southeastern United States. J. For. 2020, 118, 28-43. [CrossRef]

14. Jones, P.; Hanberry, B.; Demarais, S.; Wigley, T.B. Biodiversity Response to Stand Structural Features in Southern Pine Forests: A Literature Review; NCASI Tech. Bull: Cary, NC, USA, 2008.

15. Jones, P.D.; Hanberry, B.; Demarais, S. Stand-level wildlife habitat features and biodiversity in southern pine forests: A review. J. For. 2009, 107, 398-404.

16. Demarais, S.; Verschuyl, J.P.; Roloff, G.J.; Miller, D.A.; Wigley, T.B. Tamm review: Terrestrial vertebrate biodiversity and intensive forest management in the U.S. For. Ecol. Manag. 2017, 385, 308-330. [CrossRef]

17. Englund, O.; Berndes, G. Ho do sustainability standards consider biodiversity? WIRES En. Env. 2015, 4, 26-50. [CrossRef]

18. Fraixedas, S.; Linden, A.; Piha, M.; Cabeza, M.; Gregory, R.; Lehikoinen, A. A state-of-the-art review on birds as indicators of biodiversity: Advances, challenges, and future directions. Ecol. Indic. 2020, 118, 106728. [CrossRef]

19. Hunter, W.C.; Dickson, J.G.; Pashley, D.N.; Hamel, P.B. Bird communities of southern forests. In Proceedings of the IUFRO Conference on Restoration of Boreal and Temperate Forest: Documenting Forest Restoration Knowledge and Practices in Boreal and Temperate Ecosystems, Vijle, Denmark, 28 April-2 May 2002.

20. Rosenberg, K.V.; Dokter, A.M.; Blancher, P.J.; Sauer, J.R.; Smith, A.C.; Smith, P.A.; Stanton, J.C.; Panjabi, A.; Helft, L.; Parr, M.; et al. Decline of the North American avifauna. Science 2019, 366, 120-124. [CrossRef]

21. Moher, D.; Liberati, A.; Tetzlaff, J.; Altman, D.G.; PRISMA Group. Preferred reporting items for systematic reviews and meta-analyses: The PRISMA statement. PLoS Med. 2009, 6, e1000097. [CrossRef]

22. Dewitz, J. National Land Cover Database (NLCD) 2016 Products; U.S. Geological Survey Data Release: 2019. Available online: https: / / www.sciencebase.gov / catalog/item/5d4c6a1de4b01d82ce8dfd2f (accessed on 4 October 2020).

23. Ouzzani, M.; Hammady, H.; Fedorowicz, Z.; Elmagarmid, A. Rayyan-a web and mobile app for systematic reviews. Syst. Rev. 2016, 5, 1-10. [CrossRef]

24. Moore, W.F. Effects of Chemical Site Preparation on Vegetative, Small Mammal, and Songbird Communities in the Georgia Sandhills. Master's Thesis, University of Georgia, Athens, GA, USA, 1996.

25. Brooks, J.L.; Rodrigue, J.L.; Cone, M.A.; Miller, K.V.; Chapman, B.R.; Johnson, A.S. Small mammal and avian communities on chemically-prepared sites in the Georgia sandhills. In Proceedings of the Eighth Biennial Southern Silvicultural Conference; General Technical Report SRS-1; United States Forest Service, Southern Research Station: Albany, CA, USA, 1995; pp. 21-23.

26. Owens, F.L.; Stouffer, P.C.; Chamberlain, M.J.; Miller, D.A. Early-successional breeding bird communities in intensively managed pine plantations: Influence of vegetation succession but not site preparations. Southeast. Nat. 2014, 13, 423-443. [CrossRef]

27. Duda, L. Conservation Implications for Disturbance-Dependent Birds Breeding on Managed Pine Plantations in Southeastern Louisiana. Master's Thesis, Southeastern Louisiana University, Hammond, LA, USA, 2003.

28. Iglay, R.B.; Demarais, S.; Wigley, T.B.; Miller, D.A. Bird community dynamics and vegetation relationships among stand establishment practices in intensively managed pine stands. For. Ecol. Manag. 2012, 283, 1-9. [CrossRef]

29. Campbell, T.N. Wildlife Habitat Quality in Southern Mississippi 8 Years after Intensive Pine Plantation Establishment. Master's Thesis, Mississippi State University, Mississippi State, MS, USA, 2011.

30. Hanberry, B.B.; Hanberry, P.; Riffell, S.K.; Demarais, S.; Jones, J.C. Bird assemblages of intensively established pine plantations in coastal plain Mississippi. J. Wildl. Manag. 2012, 76, 1205-1214. [CrossRef]

31. Hanberry, B.B.; Hanberry, P.; Riffell, S.K.; Demarais, S.; Jones, J.C. Wintering birds in intensively established pine plantations of Coastal Plain Mississippi. South. J. Appl. For. 2013, 37, 91-96. [CrossRef] 
32. Lane, V.R.; Miller, K.V.; Castleberry, S.B.; Cooper, R.J.; Miller, D.A.; Wigley, T.B.; Marsh, G.M.; Mihalco, R.I. Bird community responses to a gradient of site preparation intensities in pine plantations in the Coastal Plain of North Carolina. For. Ecol. Manag. 2011, 262, 1668-1678. [CrossRef]

33. Mihalco, R.L. The Effects of Regeneration Management in Pine Plantations on Vegetation, Small Mammal, and Avian Communities on the Coastal Plain of North Carolina. Master's Thesis, University of Georgia, Athens, GA, USA, 2004.

34. Legrand, H.G.; Chamberlain, M.J.; Moser, E.B. Diversity and abundance of breeding birds in a managed loblolly pine forest in Louisiana. Am. Midl. Nat. 2007, 157, 329-344. [CrossRef]

35. Messick, E. Breeding Season Avian Community Composition and Prey Availability in Eucalyptus and Slash Pine Plantations of Southwestern Louisiana. Master's Thesis, Stephen F. Austin State University, Nacogdoches, TX, USA, 2016.

36. Sklarczyk, C. Assessing Effects of Habitat Amount vs. Configuration on Avian Diversity in Managed Pine Landscapes. Master's Thesis, Mississippi State University, Mississippi State, MS, USA, 2021, in press.

37. Posner, A.W. Bird, Plant, and Herpetofaunal Associations in Cove Forests and Pine Plantations in Mississippi. Master's Thesis, Mississippi State University, Mississippi State, MS, USA, 2012.

38. Wilson, M.D.; Watts, B.D. Breeding bird communities in pine plantations on the Coastal Plain of North Carolina. Chat 2000, 64, $1-14$.

39. Dickson, J.G.; Conner, R.N.; Williamson, J.H. Winter birds in a developing pine plantation. In Proceedings of the Annual Conference of the Southeastern Association of Fish and Wildlife Agencies, Nashville, TN, USA, 31 October 1995; Volume 49, pp. 303-313.

40. Thill, R.E.; Koerth, N.E. Breeding birds of even- and uneven-aged pine forests of eastern Texas. S.E. Nat. 2005, 4, 153-176. [CrossRef]

41. Willcox, E.V.; Giuliano, W.M. Avian community response to pine flatwoods management. For. Ecol. Manag. 2011, 261, 1928-1935. [CrossRef]

42. Iglay, R.B.; Greene, R.E.; Leopold, B.D.; Miller, D.A. Bird conservation potential of fire and herbicide treatments in thinned pine stands. For. Ecol. Manag. 2018, 409, 267-275. [CrossRef]

43. Tappe, P.A.; Thill, R.E.; Melchiors, M.A.; Wigley, T.B. Breeding bird communities on four watersheds under different forest management scenarios in the Ouachita Mountains of Arkansas. In Ouachita and Ozark Mountains Symposium: Ecosystem Management Research; Guldin, J.M., Ed.; U.S. Forest Service General Technical Report SRS-74; National Commission on Science for Sustainable Forestry Research: Asheville, NC, USA, 2004.

44. Wigley, T.B.; Baughman, W.M.; Dorcas, M.E.; Gerwin, J.A.; Gibbons, J.W.; Guynn, D.C., Jr.; Lancia, R.A.; Leiden, Y.A.; Mitchell, M.S.; Russell, K.R. Contributions of intensively managed forests to the sustainability of wildlife communities in the south. In Sustaining Southern Forests: The Science of Forest Assessment; United States Forest Service, Southern Forest Resource Assessment: Durham, NC, USA, 2000.

45. Parrish, M.C.; Demarais, S.; Wigley, T.B.; Jones, P.D.; Ezell, A.W.; Riffell, S.K. Breeding bird communities associated with land cover in intensively managed pine forests of the southeastern U.S. For. Ecol. Manag. 2017, 406, 112-124. [CrossRef]

46. Grodsky, S.M.; Moorman, C.E.; Fritts, S.R.; Castleberry, S.B.; Wigley, T.B. Breeding, early-successional bird response to forest harvests for bioenergy. PLoS ONE 2016, 11, e0165070. [CrossRef]

47. Grodsky, S.M.; Moorman, C.E.; Fritts, S.R.; Hazel, D.W.; Homyack, J.A.; Castleberry, S.B.; Wigley, T.B. Winter bird use of harvest residues in clearcuts and the implications of forest bioenergy harvest in the southeastern United States. For. Ecol. Manag. 2016, 379, 91-101. [CrossRef]

48. Paxton, B.J.; Watts, B.D. Relationship between Standing Dead Wood Dynamics and Bird Communities within North Carolina Pine Plantations; Center for Conservation Biology Technical Report Series; College of William and Mary: Williamsburg, VA, USA, 2002.

49. Homyack, J.A.; Paxton, B.J.; Wilson, M.D.; Watts, B.D.; Miller, D.A. Snags and cavity-nesting birds within intensively managed pine stands in eastern North Carolina, USA. South. J. Appl. For. 2011, 35, 148-154. [CrossRef]

50. Gottlieb, I.G.; Fletcher, R.J., Jr.; Nunez-Regueiro, M.M.; Ober, H.; Smith, L.; Brosi, B.J. Alternative biomass strategies for bioenergy: Implications for bird communities across the southeastern United States. GCB Bioen. 2017, 9, 1606-1617. [CrossRef]

51. Marshall, C.; Riffell, S.K.; Miller, D.A.; Hill, J.G.; Evans, K.O.; Rush, S.A. Bird response to intercropping switchgrass within a loblolly pine plantation. Wildl. Soc. Bull. 2017, 41, 659-665. [CrossRef]

52. Hunter, W.C.; Buehler, D.A.; Canterbury, R.A.; Confer, J.L.; Hamel, P.B. Conservation of disturbance-dependent birds in eastern North America. Wildl. Soc. Bull. 2001, 29, 440-455.

53. Swanson, M.E.; Franklin, J.F.; Beschta, R.L.; Crisafulli, C.M.; DellaSala, D.A.; Hutto, R.L.; Lindenmayer, D.B.; Swanson, F.J. The forgotten stage of forest succession: Early-succession ecosystems on forest sites. Front. Ecol. Environ. 2011, 9, 117-125. [CrossRef]

54. Darden, T.L., Jr. Bird Communities in Managed Loblolly-Shortleaf Pine Stands in East Central Mississippi. Master's Thesis, Mississippi State University, Mississippi State, MS, USA, 1980.

55. Johnson, A.S.; Landers, J.L. Habitat relationships of summer resident birds in slash pine flatwoods. J. Wildl. Manag. 1982, 46, 416-428. [CrossRef]

56. Conner, R.N.; Dickson, J.G. Relationships between bird communities and forest age, structure, species composition and fragmentation in the West Gulf Coastal Plain. Texas J. Sci. 1997, 49, 123-138.

57. Dickson, J.G.; Conner, R.N.; Williamson, J.H. Breeding bird community changes in a developing pine plantation. Bird Pop. 1993, 1, 28-35. 
58. Dickson, J.G.; Conner, R.N.; Williamson, J.H. Neotropical migratory bird communities in a developing pine plantation. Proc. Ann. Conf. S.E. Assoc. Fish Wild. Ag. 1993, 47, 439-446.

59. Greene, R.E.; Iglay, R.B.; Evans, K.O. Providing open forest structural characteristics for high conservation priority wildlife species in southeastern U.S. pine plantations. For. Ecol. Manag. 2019, 453, 117594. [CrossRef]

60. Carey, N.R. Swainson's warblers nesting in early seral pine forests in east Texas. Wils. Bull. 1996, 108, 802-804.

61. Henry, D.R. Reproductive Success and Habitat Selection of Swainson's Warbler in Managed Pine Versus Bottomland Hardwood Forests. Ph.D. Thesis, Tulane University, New Orleans, LA, USA, 2005.

62. Bassett-Touchell, C.A.; Stouffer, P.C. Habitat selection by Swainson's warblers breeding in loblolly pine plantations in southeastern Louisiana. J. Wildl. Manag. 2006, 70, 1013-1019. [CrossRef]

63. Graves, G.R. Recent large-scale colonization of southern pine plantations by Swainson's warbler Limnothlypis swainsonii. Bird Cons. Int. 2015, 25, 280-293. [CrossRef]

64. Henry, D.R.; Miller, D.A.; Sherry, T.W. Integrating wildlife conservation with commercial silviculture. In Precious Forests-Precious Earth; Zlatic, M., Ed.; IntechOpen: London, UK, 2015.

65. Perkins, C.J. Effects of clearcutting and site preparation on the vegetation and wildlife in the flatwoods of Kemper County, Mississippi. Ph.D. Thesis, Mississippi State University, Mississippi State, MS, USA, 1973.

66. Harris, L.D.; White, L.D.; Johnston, J.E.; Milchunas, D.G. Impact of forest plantation on North Florida wildlife and habitat. Proc. Ann. Conf. S.E. Assoc. Fish. Wildl. Ag. 1974, 28, 659-667.

67. Miller, K.V.; Miller, J.H. Forestry herbicide influences on biodiversity and wildlife habitat in southern forests. Wildl. Soc. Bull. 2004, 32, 1049-1060. [CrossRef]

68. Swindel, B.F.; Marion, W.R.; Harris, L.D.; Morris, L.A.; Pritchett, W.L.; Conde, L.F.; Riekerk, H.; Sullivan, E.T. Multi-resource effects of harvest, site preparation, and planting in pine flatwoods. South. J. Appl. For. 1983, 7, 6-15. [CrossRef]

69. Greene, R.E.; Iglay, R.B.; Evans, K.O.; Miller, D.A.; Wigley, T.B.; Riffell, S.K. A meta-analysis of biodiversity responses to management of southeastern pine forests-opportunities for open pine conservation. For. Ecol. Manag. 2016, 360, 30-39. [CrossRef]

70. Zobrist, K.W.; Hinckley, T.M.; Andreu, M.G.; Gehringer, K.R.; Hedman, C.W.; Lippke, B.R. Templates for Forest Sustainability on Intensively Managed Private Forests; Technical Report for National Commission on Science for Sustainable Forestry Research; National Commission on Science for Sustainable Forestry Research: Seattle, WA, USA, 2005.

71. Verschuyl, J.; Riffell, S.; Miller, D.; Wigley, T.B. Biodiversity response to intensive biomass production from forest thinning in North American forests-A meta-analysis. For. Ecol. Manag. 2011, 261, 221-232. [CrossRef]

72. Chritton, C.A. Effects of Thinning a Loblolly Pine Plantation on Nongame Bird Populations in East Texas. Master's Thesis, Stephen F. Austin State University, Nacogdoches, TX, USA, 1988.

73. Karriker, K.S. Effects of Intensive Silviculture on Breeding and Wintering Birds in North Carolina Pocosins. Master's Thesis, North Carolina State University, Raleigh, NC, USA, 1993.

74. Wilson, M.D.; Watts, B.D. Response of brown-headed nuthatches to thinning of pine plantations. Wils. Bull. 1999, 111, 56-60.

75. Thompson, J.L.R. Response of Plant and Avian Communities to Prescribed Burning and Selective Herbicide Treatments in Thinned, Mid-Rotation Loblolly Pine Plantations in Mississippi. Master's Thesis, Mississippi State University, Mississippi State, MS, USA, 2002.

76. Haines, T.K.; Busby, R.L. Prescribed burning in the South: Trends, purpose, and barriers. South. J. Appl. For. 2001, 25, 149-153. [CrossRef]

77. Ryan, K.C.; Knapp, E.E.; Varner, J.M. Prescribed fire in North American forest and woodlands: History, current practice, and challenges. Front. Ecol. Environ. 2013, 11, e15-e24. [CrossRef]

78. Burke, J.D. Effects of Silvicultural Techniques and Landscape Management on Habitat Quality and Relative Abundance for Northern Bobwhites in a Pine Plantation Forest. Master's Thesis, Louisiana State University, Baton Rouge, LA, USA, 2006.

79. Cox, J.; Widener, B. Lightning-Season Burning: Friend or Foe of Breeding Birds? Tall Timbers Res. Stn. Misc. Publ. 2008, 17, 1-16.

80. Fontaine, J.B.; Kennedy, P.L. Meta-analysis of avian and small-mammal response to fire severity and fire surrogate treatments in U.S. fire-prone forests. Ecol. Appl. 2012, 22, 1547-1561. [CrossRef]

81. Killburg, E.L.; Moorman, C.E.; DePerno, C.S.; Cobb, D.; Harper, C.A. Wild turkey prenesting-resource selection in a landscape managed with frequent prescribed fire. Southeast. Nat. 2015, 14, 134-146. [CrossRef]

82. Yeldell, N.A.; Cohen, B.S.; Little, A.R.; Collier, B.A.; Chamberlain, M.J. Nest site selection and nest survival of eastern wild turkeys in a pyric landscape. J. Wildl. Manag. 2017, 81, 1073-1083. [CrossRef]

83. Wood, J.D.; Cohen, B.S.; Prebyl, T.J.; Conner, L.M.; Collier, B.A.; Chamberlain, M.J. Time-since-fire and stand seral stage affect habitat selection of eastern wild turkeys in a managed longleaf pine ecosystem. For. Ecol. Manag. 2018, 411, 203-212. [CrossRef]

84. Singleton, L.C.; Sladek, B.G.; Burger, L.W.; Munn, I.A. Bird community response to mid-rotation management in conservation reserve program pine plantations. Wildl. Soc. Bull. 2013, 37, 189-197. [CrossRef]

85. Woodall, L.T. Response of Plant and Avian Communities to Prescribed Burning and Selective Herbicide Treatments in Thinned, Mid-Rotation Loblolly Pine Plantations in Mississippi. Master's Thesis, Mississippi State University, Mississippi State, MS, USA, 2005.

86. Sladek, B.; Burger, L.; Munn, I. Avian community response to midrotation herbicide release and prescribed burning in Conservation Reserve Program plantations. South. J. Appl. For. 2008, 32, 111-119. [CrossRef] 
87. Hunter, M.L. A mesofilter conservation strategy to complement fine and coarse filters. Conserv. Biol. 2005, 19, 1025-1029. [CrossRef]

88. Plentovich, S.; Holler, N.R.; Hill, G.E. Habitat requirements of Henslow's sparrows wintering in silvicultural lands of the Gulf Coastal Plain. Auk 1999, 116, 109-115. [CrossRef]

89. Johnson, E.I.; Dimiceli, J.K.; Stouffer, P.C. Timing of migration and patterns of winter settlement by Henslow's Sparrows. Condor 2009, 111, 730-739. [CrossRef]

90. Winiarski, J.M.; Fish, A.C.; Moorman, C.E.; Carpenter, J.P.; DePerno, C.S.; Shillaci, J.M. Nest-site selection and nest survival of Bachman's Sparrows in two longleaf pine communities. Condor 2017, 119, 361-374. [CrossRef]

91. Jones, J.; Burger, W.; Watkins, B. Bird and plant communities in a loblolly pine forest managed with prescribed fire and herbicide. For. Land. 2003, 62, 29-31.

92. Henson, P.; White, R.; Thompson, S.P. Improving implementation of the Endangered Species Act: Finding common ground through common sense. Bioscience 2018, 68, 861-872.

93. Epanchin-Niell, R.; Boyd, J. Private-sector conservation under the US Endangered Species Act: A return-on-investment perspective. Front. Ecol. Environ. 2020, 18, 409-416. [CrossRef]

94. Johnston, D.W.; Odum, E.P. Breeding bird populations in relation to plant succession on the Piedmont of Georgia. Ecology 1956, 37, 50-62. [CrossRef]

95. Noble, R.E.; Hamilton, R.B. Bird populations in even-aged loblolly pine forests of southeastern Louisiana. Proc. Ann. Conf. S.E. Assoc. Fish. Wildl. Ag. 1975, 27, 441-450.

96. Strelke, W.K.; Dickson, J.G. Effect of forest clear-cut edge on breeding birds in east Texas. J. Wildl. Manag. 1980, 44, 559-567. [CrossRef]

97. Watts, B.D.; Wilson, M.D. The use of pine plantations by worm-eating warblers in coastal North Carolina. Southeast. Nat. 2005, 4, 177-187. [CrossRef]

98. Dickson, J.G.; Williamson, J.H.; Conner, R.N.; Ortega, B. Streamside zones and breeding birds in eastern Texas. Wildl. Soc. Bull. 1995, 23, 750-755.

99. Thurmond, D.P.; Miller, K.V.; Harris, T.G. Effect of streamside management zone width on avifauna communities. South. J. Appl. For. 1995, 19, 166-169. [CrossRef]

100. Conner, R.N.; Dickson, J.G.; Williamson, J.H.; Ortego, B. Width of forest streamside zones and breeding bird abundance in eastern Texas. Southeast. Nat. 2004, 3, 669-682. [CrossRef]

101. Parrish, M.C. Effects of Green Tree Retention on Birds of Southern Pine Plantations. Ph.D. Thesis, Mississippi State University, Mississippi State, MS, USA, 2018.

102. Perry, R.; Wigley, T.B.; Melchiors, M.A.; Thill, R.E.; Tappe, P.A.; Miller, D.A. Width of riparian buffer and structure of adjacent plantations influence occupancy of conservation priority birds. Biodivers. Conserv. 2011, 20, 625-642. [CrossRef]

103. Loehle, C.; Van Deusen, P.; Wigley, T.B.; Mitchell, M.S.; Rutzmoser, S.H.; Aggett, J.; Beebe, J.A.; Smith, M.L. A method for landscape analysis of forestry guidelines using bird habitat models and the Habplan harvest scheduler. For. Ecol. Manag. 2006, 232, 56-67. [CrossRef]

104. Mitchell, M.S.; Reynolds-Hogland, M.J.; Smith, M.L.; Wood, P.B.; Beebe, J.A.; Keyser, P.D.; Loehle, C.; Reynolds, C.J.; Van Deusen, P.; White, D., Jr. Projected long-term response of Southeastern birds to forest management. For. Ecol. Manag. 2008, 256, 1884-1896. [CrossRef]

105. Freedman, B.; Zelazny, V.; Beaudette, D.; Fleming, T.; Fleming, S.; Forbes, G.; Gerrow, J.S.; Johnson, G.; Woodley, S. Biodiversity implications of changes in the quantity of dead organic matter in managed forests. Environ. Rev. 1996, 4, 238-265. [CrossRef]

106. Lanham, J.D.; Guynn, D.C., Jr. Influences of coarse woody debris on birds in southern forests. In Proceedings of the Workshop on Coarse Woody Debris in Southern Forests: Effects on Biodiversity, Athens, GA, USA, 18-20 October 1996; pp. $101-107$.

107. Dickson, J.G.; Conner, R.N.; Williamson, J.H. Snag retention increases bird use of a clear-cut. J. Wildl. Manag. 1983, 47, 799-804. [CrossRef]

108. Warren, R.C.; Hurst, G.A.; Darden, T.L., Jr. Relative abundance of cavity nesting birds on pine plantations site prepared by herbicides. In Proceedings of the Workshop on Management of Nongame Species and Ecological Communities, Lexington, Kentucky, 11-12 June 1984; pp. 197-205.

109. McComb, W.C.; Bonney, S.A.; Sheffield, R.M.; Cost, N.D. Snag resources in Florida: Are they sufficient for average populations of primary cavity-nesters? Wildl. Soc. Bull. 1986, 14, 40-48.

110. Busby, P.; Adler, P.; Warren, T.; Swanson, F. Fates of live trees retained in forest cutting units, western Cascade Range, Oregon. Can. J. For. Res. 2006, 36, 2550-2560. [CrossRef]

111. Hanberry, B.B.; Hanberry, P.; Demarais, S.; Jones, J.C. Importance of residual trees to birds in regenerating pine plantations. IForest 2012, 5, 108-112. [CrossRef]

112. Land, D.; Marion, W.R.; O'Meara, T.E. Snag availability and cavity nesting birds in slash pine plantations. J. Wildl. Manag. 1989, 53, 1165-1171. [CrossRef]

113. Lohr, S.M.; Gauthreaux, S.A.; Kilgo, J.C. Importance of coarse woody debris to avian communities in loblolly pine forests. Conserv. Biol. 2002, 16, 767-777. [CrossRef]

114. Riffell, S.; Verschuyl, J.; Miller, D.; Wigley, T.B. Potential biodiversity response to intercropping herbaceous biomass crops on forest lands. J. For. 2002, 110, 42-47. [CrossRef] 
115. Allen, A.W.; Bernal, Y.K.; Moulton, R.J. Pine Plantations and Wildlife in the Southeastern United States: An Assessment of Impacts and Opportunities; Information and Technology Report 3; U.S. Department of Interior, National Biological Service: Washington, DC, USA, 1996.

116. Mitchell, M.S.; Lancia, R.A.; Gerwin, J.A. Using landscape-level data to predict the distribution of birds on a managed forest: Effects of scale. Ecol. Appl. 2001, 11, 1692-1708. [CrossRef]

117. Mitchell, M.S.; Rutzmoser, S.H.; Wigley, T.B.; Loehle, C.; Gerwin, J.A.; Keyser, P.D.; Lancia, R.A.; Perry, R.W.; Reynolds, C.J.; Thill, R.E.; et al. Relationships between avian richness and landscape structure at multiple scales using multiple landscapes. For. Ecol. Manag. 2006, 221, 155-169. [CrossRef]

118. Chandler, C.C.; King, D.I.; Chandler, R.B. Do mature forest birds prefer early-successional habitat during the post-fledging period? For. Ecol. Manag. 2012, 264, 1-9. [CrossRef]

119. Loehle, C.; Wigley, T.B.; Rutzmoser, S.; Gerwin, J.A.; Keyser, P.D.; Lancia, R.A.; Reynolds, C.J.; Thill, R.E.; Weih, R.; White, D., Jr.; et al. Managed forest landscape structure and avian species richness in the southeastern US. For. Ecol. Manag. 2005, 214, 279-293. [CrossRef]

120. Goldstein, M.I.; Corson, M.S.; Lacher, T.E., Jr.; Grant, W.E. Managed forests and migratory bird populations: Evaluating spatial configurations through simulation. Ecol. Mod. 2003, 162, 155-175. [CrossRef]

121. Grooms, M.P.; Lanham, J.D.; Wigley, T.B. Dry Creek long-term watershed study: The effects of harvesting in streamside management zones and adjacent uplands of riparian corridors on avian communities in the Coastal Plain of Georgia. Gen. Tech. Rep. South. Res. Station. USDA For. Serv. 2006, 92, 21-25.

122. Kroll, A.J.; Ren, Y.; Jones, J.E.; Giovanini, J.; Perry, R.W.; Thill, R.E.; White, D., Jr.; Wigley, T.B. Avian community composition associated with interactions between local and landscape habitat attributes. For. Ecol. Manag. 2014, 326, 46-57. [CrossRef]

123. Foggia, J.R. Implications of Stand Adjacency and Edge for Birds in a Managed Forest Ecosystem. Master's Thesis, Mississippi State University, Mississippi State, MS, USA, 2015.

124. McWethy, D.B.; Hansen, A.J.; Verschuyl, J.P. Edge effects for songbirds vary with forest productivity. For. Ecol. Manag. 2009, 257, 665-678. [CrossRef]

125. Van Horne, B. Density as a misleading indicator of habitat quality. J. Wildl. Manag. 1983, 47, 893-901. [CrossRef]

126. Barber, D.R.; Martin, T.E.; Melchiors, M.A.; Thill, R.E.; Wigley, T.B. Nesting success of birds in different silvicultural treatments in Southeastern U.S. pine forests. Conserv. Biol. 2001, 15, 196-207. [CrossRef]

127. Loman, Z.G.; Monroe, A.P.; Riffell, S.K.; Miller, D.A.; Vilella, F.J.; Wheat, B.R.; Rush, S.A.; Martin, J.A. Nest survival modelling using a multi-species approach in forests managed for timber and biofuel feedstock. J. Appl. Ecol. 2018, 55, 937-946. [CrossRef]

128. Holbrook, H.T.; Vaughan, M.R.; Bromley, P.T. Wild turkey habitat preferences and recruitment in intensively managed Piedmont forests. J. Wildl. Manag. 1987, 51, 187. [CrossRef]

129. Foggia, J.R.; Rush, S.A.; Miller, D.A.; Wigley, T.B.; Martin, J.A. Effects of forest structure and harvest-induced edges on predation risk. Wildl. Soc. Bull. 2018, 42, 237-245. [CrossRef]

130. Novak, L.D.; Comer, C.E.; Conway, W.C.; Scognamillo, D.G.; Gay, R.D. Nesting ecology of early-successional birds in restored longleaf and loblolly pine stands. Wils. J. Orn. 2016, 128, 314-327. [CrossRef]

131. Hazler, K.R.; Amacher, A.J.; Lancia, R.A.; Gerwin, J.A. Factors influencing Acadian flycatcher nesting success in an intensively managed forest landscape. J. Wildl. Manag. 2006, 70, 532-538. [CrossRef]

132. Davis, J.R.; Barnhill, H.R.; Guynn, D.C., Jr.; Larkin, R.E.; Baughman, W.M. Wild turkey nesting ecology in the Lower Coastal Plain of South Carolina. Proc. Ann. Conf. S.E. Assoc. Fish. Wildl. Ag. 1995, 49, 454-465.

133. Palmer, W.E.; Hurst, G.A.; Stys, J.E.; Smith, D.R.; Burk, J.D. Survival rates of wild turkey hens in loblolly pine plantations in Mississippi. J. Wildl. Manag. 1993, 57, 783-789. [CrossRef]

134. Miller, D.A.; Conner, L.M. Seasonal and annual home ranges of female eastern wild turkeys in a managed pine landscape in Mississippi. Proc. S.E. Assoc. Fish. Wildl. Ag. 2005, 59, 89-99.

135. Wigley, T.B.; Melchiors, M.A. Wildlife habitat and communities in streamside management zones: A literature review for the eastern United States. NCASI Tech. Bull. 1994, 2, 573-574.

136. Cornwall, W. Is wood a green source of energy? Scientists are divided. Science 2017, 355, 18-21. [CrossRef]

137. Kline, K.L.; Dale, V.H.; Rose, E.; Tonn, B. Effects of production of woody pellets in the southeastern United States on the sustainable development goals. Sustainability 2021, 13, 821. [CrossRef]

138. Costanza, J.K.; Abt, R.C.; McKerrow, A.J.; Collazo, J.A. Bioenergy production and forest landscape change in the southeastern United States. GCB Bioenergy 2016, 9, 924-939. [CrossRef]

139. Dale, V.H.; Parish, E.; Kline, K.L.; Tobin, E. How is wood-based pellet production affecting forest conditions in the southeastern United States? For. Ecol. Manag. 2017, 396, 143-149. [CrossRef]

140. Brandeis, C.; Abt, K.L. Roundwood use by southern wood pellet mills: Findings from timber product output mill surveys. J. For. 2019, 117, 427-434. [CrossRef]

141. Melvin, M.A. 2020 National Prescribed Fire Use Report; Technical Bulletin 04-20; Coalition of Prescribed Fire Councils, Inc.: Washington, DC, USA, 2020.

142. Sallabanks, R.; Arnett, E.B. Accommodating Birds in Managed Forests of North America: A Review of Bird-Forestry Relationships In Bird Conservation Implementation and Integration in the Americas; US Forest Service General Technical Report PSW-191; United States Forest Service: Albany, CA, USA, 2005; pp. 345-372. 